\title{
New discoveries and interpretations of hominid fossils and artifacts from Vindija Cave, Croatia
}

\author{
James C.M. Ahern ${ }^{a *}$, Ivor Karavanić ${ }^{\mathrm{b}}$, Maja Paunovićc ${ }^{\mathrm{c}}$ Ivor Jankovićd, \\ Fred H. Smith \\ ${ }^{a}$ Department of Anthropology, University of Wyoming, Box 3431, Room 123, Anthropology Bld., Laramie, WY 82071-3431, USA \\ ${ }^{\mathrm{b}}$ Department of Archaeology, Faculty of Philosophy, University of Zagreb, Ivana Lučiča 3, 10000 Zagreb, Croatia \\ ${ }^{\mathrm{c}}$ Institute of Quaternary Palaeontology and Geology, Croatian Academy of Sciences and Arts, Zagreb, Croatia \\ dInstitute for Anthropological Research, Amruseva 8, 10000 Zagreb, Croatia \\ ${ }^{\mathrm{e}}$ Department of Sociology/Anthropology, Loyola University, Chicago, IL 60626, USA
}

Received 30 January 2003; accepted 30 September 2003

\begin{abstract}
Beginning with excavations during the 1970s, Vindija Cave (Croatia) has yielded significant Middle and Upper Paleolithic fossil and archaeological finds. We report on seven recently identified hominid fossils, a newly associated partial hominid cranial vault from level $\mathrm{G}_{3}$, nine possible bone retouchers, and a revised interpretation of the Mousterian artifact assemblage from the site. This new information reinforces our knowledge of the complex biocultural phenomena revealed in unit $G$ and earlier deposits at Vindija. Six of the new hominid fossils derive from stratigraphic units $\mathrm{G}$ and I, while one lacks exact provenience. All specimens preserving diagnostic anatomy are from Neandertals. One of the postcranial remains, a radius fragment which exhibits Neandertal-like anatomy, comes from level $G_{1}$ and is congruent with the previously established association of Neandertals with an early Upper Paleolithic industry at the site. The partial cranial vault represents the most complete Neandertal from Vindija. The possible retouchers derive from unit G. Our analysis of these artifacts suggests that both percussion and pressure techniques may have been used by Neandertals in the final stage of tool production (retouching).

This paper also presents a revision of the artifact analysis for late Mousterian level $\mathrm{G}_{3}$. We separated raw materials into two main groups due to the differing ways that the materials fracture and the differing morphology of the debitage. The use of raw material in level $G_{3}$ is different from earlier Middle Paleolithic levels at Vindija. This indicates that the $G_{3}$ late Neandertals were making choices regarding source material somewhat more like the Upper Paleolithic people at the site. When interpreted within a larger regional framework, the Vindija archaeological and hominid fossil remains demonstrate a complex, mosaic pattern of biocultural change in the Late Pleistocene of south-central Europe.
\end{abstract}

(C) 2003 Published by Elsevier Ltd.

Keywords: Vindija; Neandertal; Middle Paleolithic; Retouchers; Lithic Analysis; Lithics; Human Evolution; South-Central Europe

\footnotetext{
* Corresponding author. Tel.: +1-307-766-4911; fax: +1-307-766-2473

E-mail addresses: jahern@uwyo.edu (J.C.M. Ahern), ikaravan@mudrac.ffzg.hr (I. Karavanić), zpgk@mahazu.hazu.hr (M. Paunović), ivor_jankovic@yahoo.com (I. Janković), fsmith3@luc.edu (F.H. Smith).
} 


\section{Introduction}

Vindija Cave, located in northwestern Croatia, has yielded numerous hominid fossils and archaeological remains. Most of the Vindija discoveries span the crucial period in Europe of $25-45 \mathrm{ka}$, which saw the appearance of modern humans, the Middle to Upper Paleolithic transition, and the disappearance of Neandertals. Vindija Cave has contributed significantly to our understanding of the complexity of these events. The latest Mousterian-associated hominid fossils from the site exhibit a mosaic of Neandertal and early modern human anatomy which suggests at least some degree of regional evolutionary continuity in Europe (Smith and Ranyard, 1980; Wolpoff et al., 1981; Smith, 1984, 1994; Frayer et al., 1993). Also significant is the fact that Neandertal fossils dating to less than $30 \mathrm{ka}$ are associated with the earliest Upper Paleolithic artifacts from the site (Smith and Ahern, 1994; Karavanić, 1995; Karavanić and Smith, 1998). Since systematic excavations at the site ended in 1986, research has focused on identification and analysis of previously overlooked hominid fossils and artifacts (e.g., Smith and Ahern, 1994), continued analysis of the fossil and archaeological samples (e.g., Trinkaus and Smith, 1995; Karavanić and Smith, 1998; Ahern et al., 2002), and the site's chronology (Karavanić et al., 1998; Smith et al., 1999; Wild et al., 2001). In this paper, we report on additional fossil and archaeological discoveries and interpretations that enhance our understanding of the biology and behavior of the Vindija hominids and of the mosaic pattern of biocultural change in the Late Pleistocene of south-central Europe.

\section{History of excavation}

The first published mention of Vindija Cave was made by D. Hirc (Hirc, 1878) in Prirodni Zemljopis Hrvatske (Natural Geography of Croatia). Hirc reported the discovery of 38 bone fragments and 20 pottery sherds from the cave. He further cited mention of the cave in an 1801 note found at the parish in Donja Voća. Gorjanović-Kramberger, leader of the Krapina excavations (1899-1905), was aware of the cave and made mention of its importance in a letter dated 1926 (cited in Vukovic, 1949).

Excavations by S. Vuković began in 1928 and continued, with many interruptions, for the next thirty years (Vuković, 1949, 1950; Karavanić, 1995). Vuković's excavations were both inside and in front of the cave and were mostly limited to the upper levels of the deposits (Vuković, 1949, 1950). He identified three Paleolithic cultural periods: Mousterian, Aurignacian, and Magdalenien (which he later called Gravettian [Vuković, 1970]) and also published an analysis of the Mesolithic archaeology from the site (Vuković, 1961). Vuković recognized as many as seven stratigraphic units at Vindija, but these cannot be correlated with the stratigraphy reported from more recent excavations.

Excavations at Vindija, under the direction of M. Malez, began in July 1974 and continued every season through 1986. During that time period, approximately 60 hominid specimens associated with Mousterian or earliest Upper Paleolithic industries and 45 specimens associated with Epigravettian artifacts were discovered. Furthermore, extensive archaeological and faunal remains were collected. Numerous publications have dealt with the findings from Vindija (Malez, 1975, 1980; Malez and Rukavina, 1979; Malez et al., 1980; Wolpoff et al., 1981; Malez and Ullrich, 1982; Smith et al., 1985, 1999; Smith and Ahern, 1994; Karavanić, 1995; Trinkaus and Smith, 1995; Karavanić et al., 1998; Wild et al., 2001; Ahern et al., 2002).

\section{Stratigraphy and chronology}

Vindija Cave is located on the southwest side of Križnjak Peak at an elevation of $275 \mathrm{~m}$ above sea level (Malez et al., 1980). Križnjak Peak is part of the Ravna Gora, which is a southeastern extension of the Alps. The cave itself is a single chamber measuring approximately $50 \mathrm{~m}$ deep, $28 \mathrm{~m}$ wide, and more than $10 \mathrm{~m}$ in height. According to Malez and colleagues (Malez et al., 1984), the cave was formed in Upper Baden Formation sandstone and limestone during the Middle Pliocene as the result of tectonic folding and cracking of lake basin deposits. The subterranean cavern was given its 


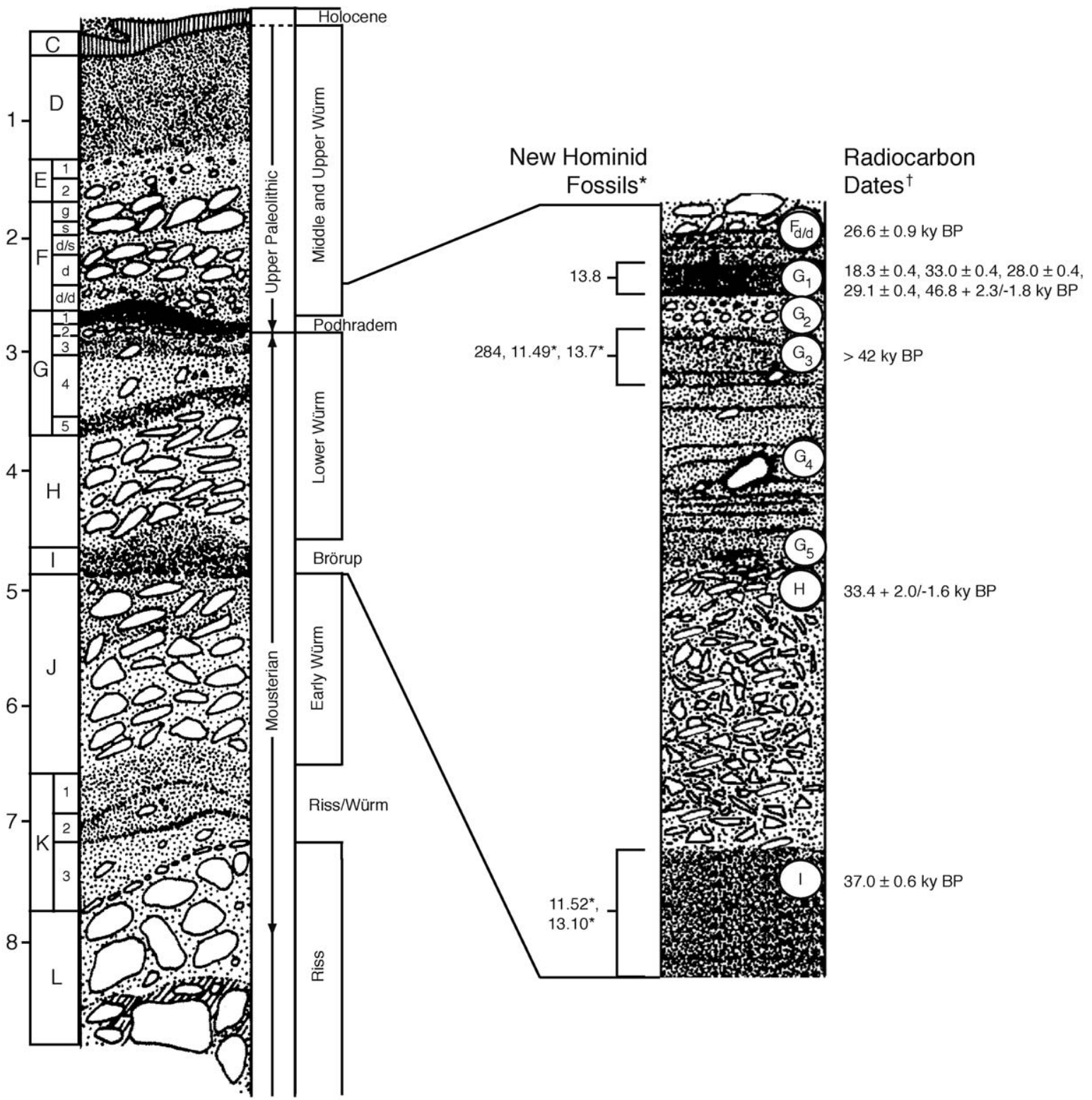

Fig. 1. The Vindija stratigraphic sequence. ${ }^{*}$ Vi 13.8 and 284 have solid provenience. Provenience as shown for fossils denoted with a " $\star$ is probable, but not certain. Other specimens described in the text are not shown because they either lack provenience (Vi 11.48 , 13.9) or are provenienced to just "G" (Vi 11.47). "See text for interpretation of the radiocarbon dates.

modern opening during the Upper Pliocene as the Šokot creek cut the valley that Vindija Cave now overlooks. Deposition in the cave probably began in the Early Pleistocene (Malez et al., 1984).
Malez and Rukavina (1979) divided the Vindija deposits into 14 stratigraphic units, labeled A through N (Fig. 1). A, B, and C are Holocene, while D through $\mathrm{N}$ are Pleistocene. Three of these 
Table 1

Radiocarbon dates from the Vindija Cave ${ }^{\mathrm{a}}$

\begin{tabular}{llccc}
\hline Layer & Sample & ${ }^{14} \mathrm{C}$ age $(\mathrm{ka})$ & Lab. no. & Reference \\
\hline $\mathrm{E}$ & Cave bear & $18,500 \pm 300$ & Z-2447 & Obelic et al., 1994 \\
$\mathrm{F}$ & Charcoal & $24,000 \pm 3300$ & Z-612 & Srdoc et al., 1984 \\
$F$ & Charcoal & $29,700 \pm 2000$ & Z-613 & Srdoc et al., 1984 \\
$F$ & Charcoal & $27,000 \pm 600$ & Z-551 & Srdoc et al., 1984 \\
$\mathrm{F} / \mathrm{d} / \mathrm{d}$ & Cave bear & $26,600 \pm 930$ & Z-2433 & Obelic et al., 1994 \\
$\mathrm{G}_{1}$ & Cave bear & $18,280 \pm 440$ & Z-2432 & Obelic et al., 1994 \\
$\mathrm{G}_{1}$ & Cave bear & $33,000 \pm 400$ & ETH-12714 & Karavanic, 1995 \\
$\mathrm{G}_{1}$ & Cave bear & $46,800+2300 /-1800$ & VERA-1428 & Wild et al., 2001 \\
$\mathrm{G}_{1}$ & Neandertal & $29,080 \pm 400$ & OxA-8296 & Smith et al., 1999 \\
$\mathrm{G}_{1}$ & Neandertal & $28,020 \pm 360$ & OxA-8295 & Smith et al., 1999 \\
$\mathrm{G}_{3}$ & Neandertal & $>42,000$ & Ua-13873 & Krings et al., 2000 \\
$\mathrm{H}_{\mathrm{I}}$ & Cave bear & $33,400+2000 /-1600$ & VRI-1125 & Wild et al., 2001 \\
$\mathrm{J}$ & Cave bear & $37,000 \pm 600$ & VERA-0109 & Wild et al., 2001 \\
\hline
\end{tabular}

aAdapted from Wild et al., 2001.

units, $F, G$, and $K$, are further subdivided into multiple levels (Wolpoff et al., 1981). Although some of the cave sediments were affected by cryoturbation and/or by ice-wedging, the stratigraphic sequence was based on the remaining undisturbed part (Malez and Rukavina, 1979; Malez and Ullrich, 1982; Karavanić and Smith, 1998; Paunović et al., 2001).

Malez's excavations yielded 4 to 5 stratigraphically distinct hominid samples associated with Middle (level $\mathrm{G}_{3}$ and, as reported in this paper, unit I) and Upper (levels $G_{1}$ and $F_{d}$ and unit D) Paleolithic industries. The largest of these samples is from level $\mathrm{G}_{3}$. Morphologically, these fossils are attributable to Neandertals, but many (e.g., Smith, 1982, 1984, 1994; Wolpoff et al., 1981; Frayer et al., 1993; Wolpoff, 1999) have argued for their evolutionary intermediacy between earlier Neandertals, such as those from nearby Krapina, and early modern Europeans. The six specimens from level $G_{1}$ represent the latest Neandertals in Europe (Smith and Ahern, 1994; Smith et al., 1999). The ten specimens from level $\mathrm{F}$ are associated with an Aurignacianlike industry (Karavanić, 1995; Wolpoff et al., 1981). Their morphology is enigmatic, resembling both Neandertals and modern humans in the limited anatomy that is preserved (Wolpoff et al., 1981;
Smith et al., 1985; Wolpoff, 1999). The most recent Vindija hominid sample is from level D and is associated with a late Upper Paleolithic industry. These level D hominids are clearly anatomically modern humans (Wolpoff et al., 1981).

Direct radiometric dating of animal and human bones has been conducted at different laboratories in the attempt to better define the chronology of the Neandertal fossil and cultural remains from Vindija (Karavanić et al., 1998; Rink et al., 1999; Smith et al., 1999; Wild et al., 2001). A compilation of all ${ }^{14} \mathrm{C}$ data obtained for the Vindija Cave is given in the Table 1. The direct AMS radiocarbon dating of two Neandertal specimens (Vi 207 and 208) from level $G_{1}$ yielded dates of $29,080 \pm 400$ yrs BP and 28,020 \pm 360 yrs BP, respectively (Smith et al., 1999). However, nondestructive $\gamma$-ray spectrometry and electron spin resonance (ESR) dating of level $\mathrm{G}_{1}$ has yielded significantly older dates (Karavanić et al., 1998; Rink et al., 1999). The older dates should be regarded as suspect because of the relatively low quantity of uranium in the measured pieces and the high standard errors of $\gamma$-ray dating (Churchill and Smith, 2000). Given radiometric dates for other levels in the cave, the presence of Upper Paleolithic elements in the $G_{1}$ archaeological assemblage, and inconsistent $\gamma$-ray results, the 
radiocarbon-especially AMS-dates should be given priority (Smith et al., 1999; Wild et al., 2001). Nevertheless, it must be noted that the application of the ${ }^{14} \mathrm{C}$ method to animal bones from this site is not straightforward because of the poor preservation state of the collagen in most specimens. Recently at VERA laboratory in Vienna, AMS dating was attempted for cave bear bone samples from units $\mathrm{F}$ through $\mathrm{H}$ of the cave sediments, and, unfortunately, the collagen of all samples was already highly degraded (Wild et al., 2001). Thus, the ages derived from AMS measurements on Vindija animal bone should be treated with caution: the young ages obtained on samples from layers $\mathrm{H}$, I and $\mathbf{J}$ may be due to an insufficient cleanup of the samples (Wild et al., 2001), or due to bio- and/or cryoturbations registered in the Late Pleistocene deposits of the cave (Paunović et al., 2001). Also, the age for one cave bear bone sample from level $\mathrm{G}_{1}$ of $33,000 \pm 400 \mathrm{yrs} \mathrm{BP}$ was obtained at ETH Zürich, while at the same time in the cave bear specimen from level $G_{3}$, sufficient collagen for an age determination was not present (Karavanić, 1995).

When the radiometric dates and other chronologically pertinent evidence (e.g., fauna, sedimentology) are taken together, it is possible to provide a reasonable, albeit not definite, chronology for the Vindija sequence. A U/Th date of 114,000 ka (Wild et al., 1987/1988) combined with fauna and sediments similar to those from Krapina indicate that unit $\mathrm{K}$ is likely Riss-Würm interglacial in age. Units $\mathrm{H}$ and $\mathrm{F}$ and levels $\mathrm{G}_{4}$ and $\mathrm{G}_{3}$ represent colder periods, while $G_{1}$ and $G_{5}$ represent warmer periods (Malez et al., 1984; Wolpoff et al., 1981). Based on correlation with sites from the Moravian Karst (Wolpoff et al., 1981; Smith et al., 1985), the single AMS radiocarbon date of $>42,000$ (Krings et al., 2000; see Table 1), and a U/Th date of cave bear bone of $41,000+1000 /$ -900 yrs BP (Wild et al., 2001), the important hominid-fossil bearing level $\mathrm{G}_{3}$ correlates to the Lower Würm stadial (following the Moravian Karst sequence: Musil and Valoch, 1966; Valoch, 1968). Radiocarbon dates for the Lower Würm stadial level (7a) at Kulna range from 38,600+920/ $-800 \mathrm{yrs}$ BP to $45,660+2850 /-2200 \mathrm{yrs}$ BP (Valoch, 1977/1978, 1981).
Level $G_{1}$ is of special importance in that it yielded Neandertal fossils, both Mousterian and Upper Paleolithic lithic artifacts and early Upper Paleolithic bone points. This level represents a warmer period, likely the Podhradem interstadial, and consists of a characteristic reddish-brown clay. The color of this clay is so distinct that its presence within bone specimens has been used confidently to determine their provenience (Smith and Ahern, 1994; Karavanić and Smith, 1998). Three of the five radiocarbon dates for level $\mathrm{G}_{1}$ are consistent with a Podhradem date. The two remaining dates correspond either to the Lower Würm $(46,800+2300 /-1800$ yrs BP, see Table 1) or Middle Würm (18,280 4440 yrs BP, see Table 1) stadials. The spurious dates, although possibly the result of contamination, highlight the possibility that $G_{1}$ collections include materials mixed from underlying and/or overlying levels via cryoturbation in parts of the cave. Such a scenario has been suggested to explain the mix of Neandertal fossils, Mousterian lithics, and Upper Paleolithic bone points (Stringer, 1982; Kozlowski, 1996; Montet-White, 1996; Zilhão and d'Errico, 1999). However, none of the lithics from $G_{1}$ exhibit modification that would be unequivocally suggestive of vertical movement through cryoturbation (Karavanić and Smith, 1998, 2000). Furthermore, the Aurignacian-type split-based bone point and virtually all the hominid remains from the level were excavated from non-cryoturbated areas (Wolpoff et al., 1981). Finally, the direct AMS radiocarbon dates for two $G_{1}$ Neandertal specimens places them well within the time range of both the Podhradem interstadial and the central European Aurignacian. Although contemporary, the exact circumstances of the Neandertal association with the early Upper Paleolithic are not known. Unit F, with its partly Neandertal-like fossils and Aurignacian artifacts (in $\mathrm{F}_{\mathrm{d} / \mathrm{d}}$ and $\mathrm{F}_{\mathrm{d}}$ ), dates to the Middle Würm stadial based on its cold-adapted fauna and associated radiocarbon dates (see Table 1). Compared to the case of level $G_{1}$, the possibility that cryoturbation caused the association of Neandertal-like fossils with Aurignacian artifacts is stronger for $F_{d / d}$ and $F_{d}$. Yet, given the evidence from $G_{1}$, such an association in the lower $\mathrm{F}$ unit would not be 
Table 2

Newly associated and newly identified Vindija cranial specimens

\begin{tabular}{|c|c|c|c|c|c|}
\hline $\begin{array}{l}\text { Primary } \\
\text { specimen } \\
\text { number }\end{array}$ & $\begin{array}{l}\text { Other specimen } \\
\text { numbers }\end{array}$ & $\begin{array}{c}\text { New inventory } \\
\text { numbers }\end{array}$ & Description & Level & $\begin{array}{l}\text { Discovery year } \\
\text { (year identified) }\end{array}$ \\
\hline $\begin{array}{l}284-230- \\
255-256\end{array}$ & $\begin{array}{l}284^{\mathrm{a}} \\
230^{\mathrm{a}} \\
255^{\mathrm{a}} \\
256^{\mathrm{a}}\end{array}$ & $\begin{array}{l}11.19 \\
11.22 \\
11.37 \\
11.35\end{array}$ & $\begin{array}{l}\text { Right supraorbital segment attached } \\
\text { to a large portion of central and } \\
\text { posterior frontoparietal fragment }\end{array}$ & $\mathrm{G}_{3}^{\mathrm{b}}$ & $\begin{array}{l}\text { 1976-1978 (all four } \\
\text { associated in 1996) }\end{array}$ \\
\hline 11.47 & - & 11.47 & $\begin{array}{l}\text { Frontal squama fragment with } \\
\text { temporal line }\end{array}$ & $\mathrm{G}^{\mathrm{c}}$ & 1976 (1996) \\
\hline 11.48 & - & 11.48 & Posterior frontal squama fragment & Unknown & 1974 (1996) \\
\hline 11.49 & - & 11.49 & $\begin{array}{l}\text { Frontal squama fragment with } \\
\text { temporal line }\end{array}$ & $\mathrm{G}_{3}^{\mathrm{c}}$ & 1978 (1996) \\
\hline 11.52 & & 11.52 & Partial right mandibular ramus & $\mathrm{I}^{\mathrm{c}}$ & 1975 (2002) \\
\hline 13.7 & - & 13.7 & Partial left ilium & $\mathrm{G}_{3}^{\mathrm{c}}$ & $1978(2002)$ \\
\hline 13.8 & - & 13.8 & Left proximal radius shaft & $\mathrm{G}_{1}^{\mathrm{b}}$ & $1974(2002)$ \\
\hline 13.10 & - & 13.10 & Inferior angle of right scapula & $\mathrm{I}^{\mathrm{c}}$ & 1975 (2002) \\
\hline
\end{tabular}

apreviously described by Wolpoff et al. (1981).

${ }^{b}$ Provenience considered definite.

${ }^{\mathrm{c}}$ Probable provenience, based on specimen label only.

unprecedented. Given the limited anatomy preserved by the unit $\mathrm{F}$ fossils, it is also not possible to rule out the possibility that the hominids were early moderns that retained some Neandertal-like features.

\section{Note on the new numbering system}

In order to avoid confusion caused by the discovery of additional hominid remains found during excavations between 1981 and 1986 or recently among the faunal collections, the Institute of Quaternary Paleontology and Geology instituted a new numbering system during the late 1990s. The system has only been applied to hominid remains from unit $\mathrm{F}$ and below, which are Aurignacian and Mousterian in age (the Epigravettian remains from unit $\mathrm{D}$ are excluded from this system). This new system uses " 11 " for all hominid cranial remains with the number to the right of decimal designating the individual specimen (e.g., "11.48"). Hominid dental remains are designated as " 12 ", and the postcranial parts as "13". Following the same pattern, a similar system, using instead "21," "22," "23," has been applied to all Epigravettian or more recent human finds (Units D and C). A full listing of the Aurignacian and Mousterian associated hominids' inventory numbers (old and new) will be provided in the forthcoming catalogue (Rabeder et al., in press). The possible hominid specimens found among faunal assemblages are provisionally inventoried as "33," with the number to the right of decimal designating the individual specimen. For " 33 " specimens that are eventually identified as hominid, their inventory numbers will change to "11," " 12, ," or " 13 ," with the specimen number given to the right of the decimal.

In order to avoid confusion, we will use the old inventory numbers for all earlier described Vindija specimens (see Wolpoff et al., 1981; Malez and Ullrich, 1982; Smith et al., 1985, Smith and Ahern, 1994), while the new specimens are referred to under the new numbering system. Old and new inventory numbers and other details for all of the Vindija specimens described here are given in Table 2. 


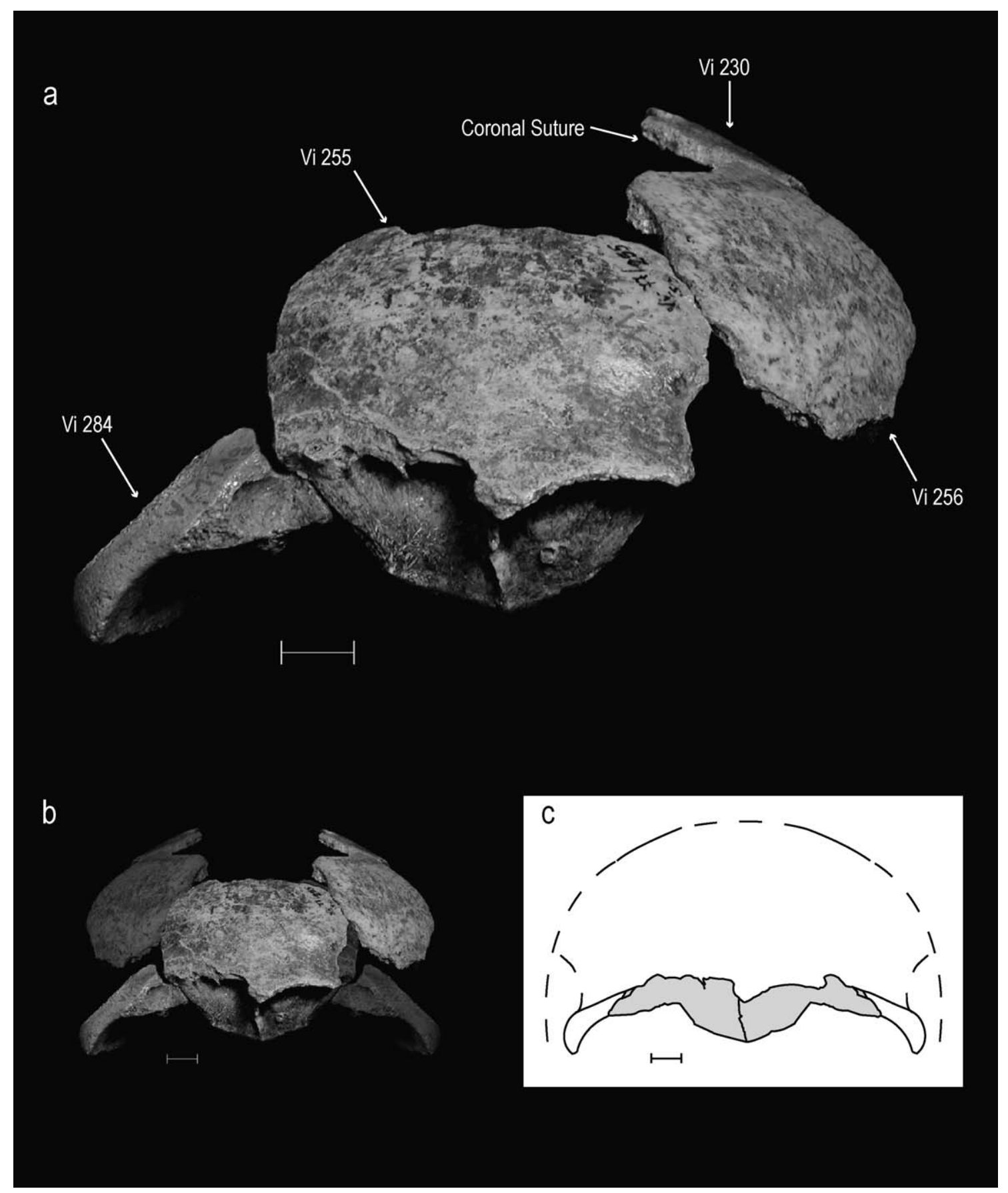

Fig. 2. The partial calotte, Vindija 284-230-255-256, in norma frontalis: (A) naturally articulated; (B) symmetrically reconstructed; and (C) artistic reconstruction. Scale is $1 \mathrm{~cm}$. 


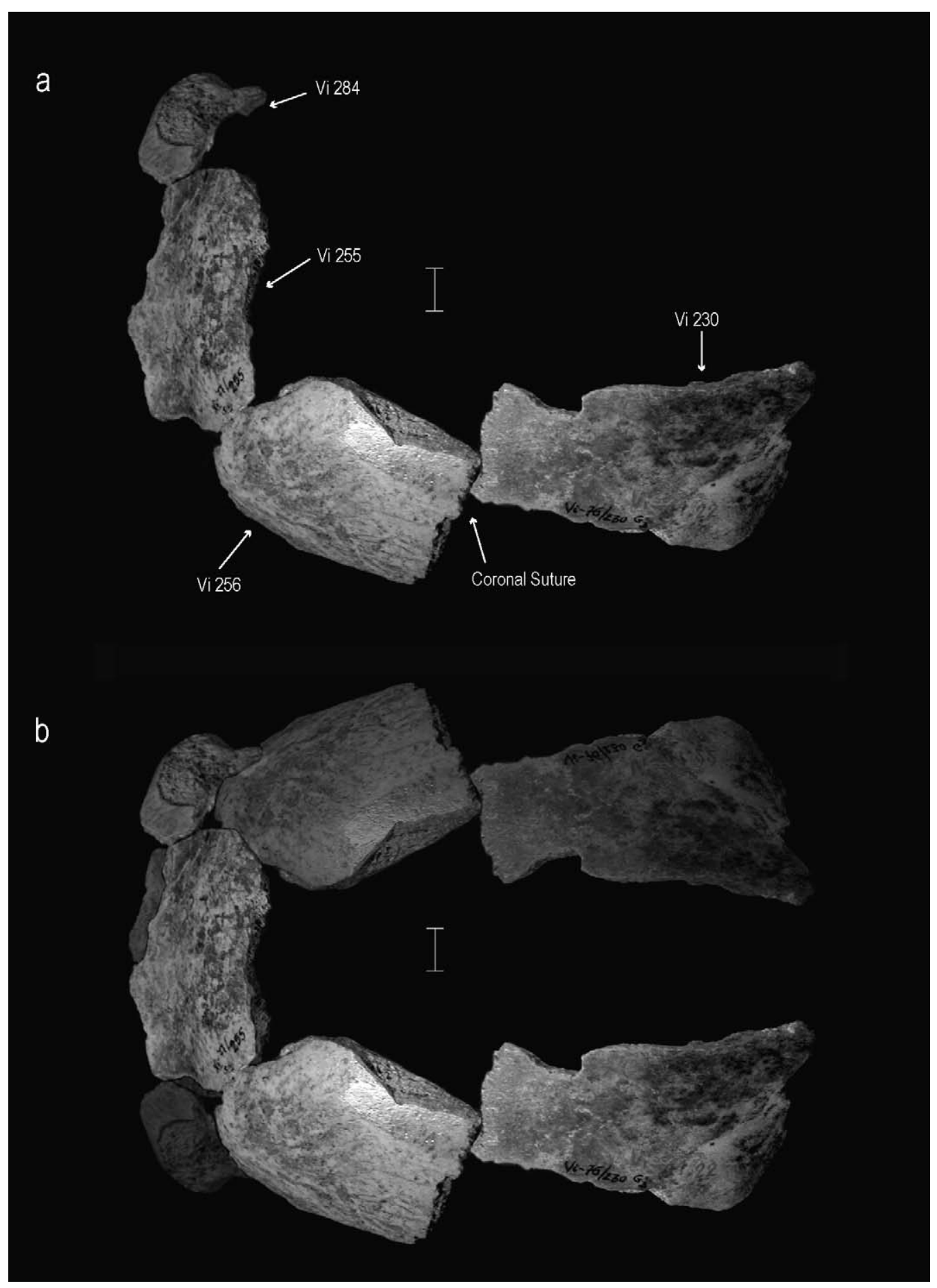

Fig. 3. Superior view of Vindija 284-230-255-256, a partial calotte: (A) naturally articulated and (B) symmetrically reconstructed. Scale is $1 \mathrm{~cm}$. 


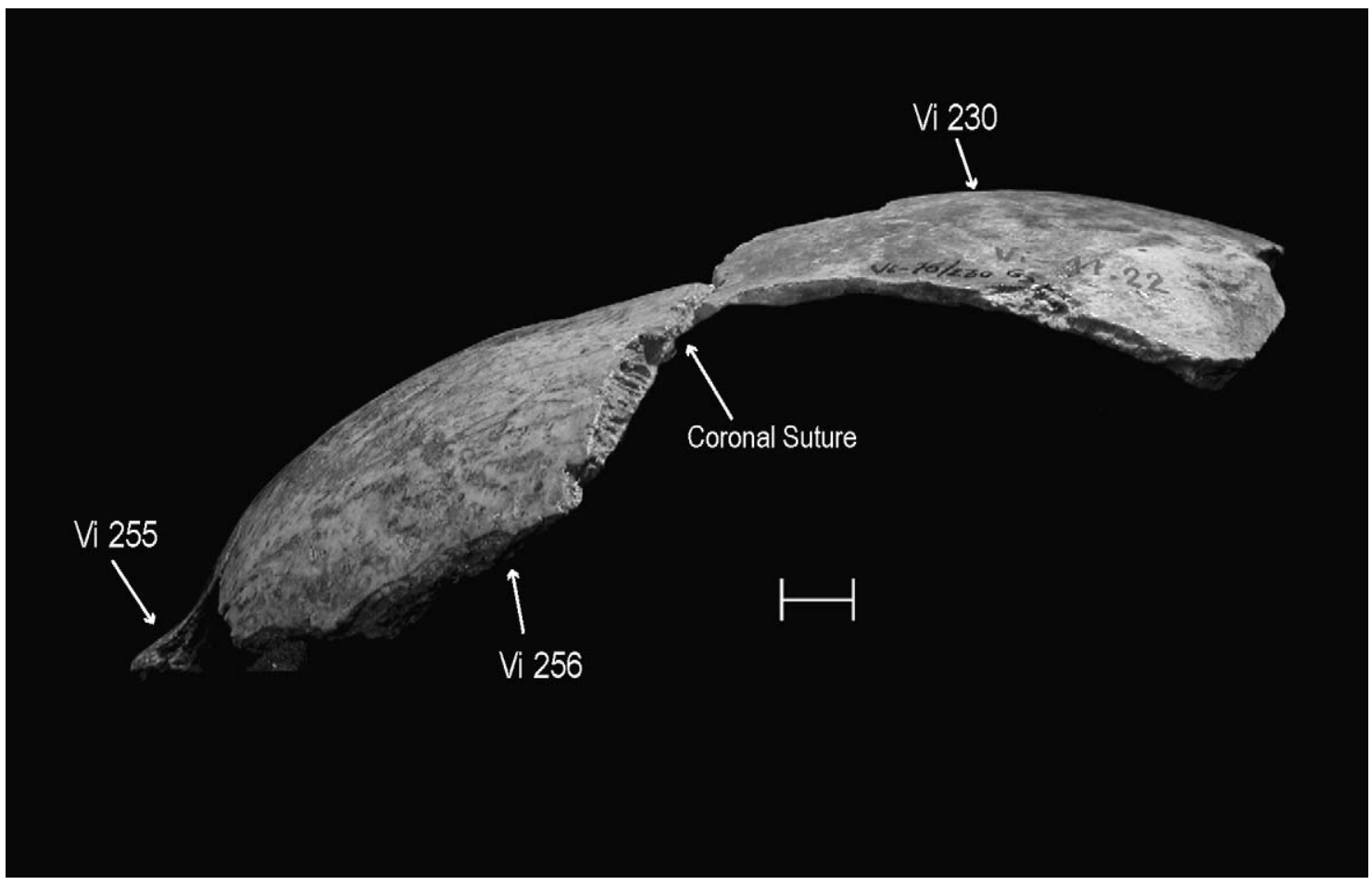

Fig. 4. Lateral view of the partial calotte, Vi 284-230-255-256. The supraorbital piece, Vi 284, is not visible in this view. Scale is $1 \mathrm{~cm}$.

\section{New hominid fossil associations and specimens}

This study reports on a newly associated anterior cranial vault and seven undescribed hominid fossils from Vindija Cave (see Table 2). The newly associated partial vault, Vi 284-230-255-256, consists of four previously described specimens from level $\mathrm{G}_{3}$ (Wolpoff et al., 1981). When articulated, these four fossils comprise the most complete cranial vault from Vindija, more complete than the Vi 261-277-278 frontal published by Malez and colleagues (Malez et al., 1980; see also Smith and Ranyard, 1980; Wolpoff et al., 1981). In his examination of the Vindija faunal remains, T. D. White recognized numerous specimens as possibly hominid. Of these, we describe here four cranial specimens and three postcranial specimens that are clearly hominid. Two of the new specimens are small frontal fragments preserving the temporal line (Vi 11.47, Vi 11.49). The other two fossils consist of posterior portions of the frontal squama (Vi 11.48) and mandible (Vi 11.52). The post- cranial remains comprise a large portion of left ilium (Vi 13.7), a section of left proximal radial diaphysis (Vi 13.8), and a portion of right scapula (13.10). With the exceptions of Vi 284-230-255-256 and Vi 13.8, provenience is based on the excavation labels written on the specimens and should be regarded as tentative (see Table 2). The exact provenience of Vi 284-230-255-256 is known from excavation witnesses, while Vi 13.8's attribution to $G_{1}$ is based on the characteristic red clay embedded in the fossil. Vi 11.52 and Vi 13.10 are of particular interest since they tentatively come from unit I, and thus represent the oldest known hominid fossils from Vindija.

\section{Vi 284-230-255-256: a newly associated partial cranial vault}

This newly associated cranial vault specimen (Figs. 2-4) comprises four previously described fossils from level $\mathrm{G}_{3}$. Vindija 284, a supraorbital segment, articulates with the inferomedial frontal 
squama Vi 255, which articulates with Vi 256, a section of superolateral frontal squama. Vi 256 articulates with the partial parietal Vi 230. These four specimens comprise what is a single partial vault and supraorbital region, designated as $\mathrm{Vi}$ 284-230-255-256. Wolpoff et al. (1981) recognized the probable association between the frontal fragments Vi 255 and Vi 256 with the partial left parietal, Vi 230. Vi 284, a right lateral supraorbital, articulates with Vi 255 . If any of the articulations appear artificial, that between the parietal 230 and frontal 256 is most problematic. No clear alignment can be made between these two along their coronal sutural surfaces. Although all of the specimens differ in their coloration, this is not out of the ordinary for the Vindija fossils, given the clear articulation of vastly differently colored specimens from the site (e.g., Vi 275 and Vi 261). All of the articulations among Vi 255, Vi 256, Vi 284, and Vi 230 have been eroded and abraded to varying degrees. Associations among the four specimens are based on similarities in form and size, as well as articulation along adjoined pieces. The four specimens combine to form the most complete of the Vindija cranial specimens, and the conjoined vault is comparable in preservation to the Krapina frontal specimens $\mathrm{Kr} 4$ and $\mathrm{Kr} 27 / 28$ (see Radovčić et al., 1988; Ahern, 1998). Wolpoff and colleagues (Wolpoff et al., 1981) gave brief and separate descriptions of Vi 284 and Vi 230255-256, while we provide here a more detailed description and analysis of these fossils as the partial vault of a single individual.

The supraorbital portion, Vi 284, does not preserve any of the frontal squama. Vi 255 is an inferomedial section of squama and posterior sinus wall, while Vi 256 is a posterolateral squamal piece from the left side. A broad sagittal torus is present in the supraglabellar region. This torus continues superiorly as a slight swelling and is still palpable at the level of the superior break. Like Vi 260, Vi 262 , and some robust modern humans, the frontal squama is fairly vertical relative to the anterior face of the supraorbital torus (Wolpoff et al., 1981). The squama arises from a very shallow supratoral sulcus. However, the sulcus is more pronounced and verticality of the squama is significantly less than that exhibited by the juvenile frontal Vi 227. Very little bilateral frontal bossing is present, with the squama gradually curving toward the coronal suture. Wolpoff and colleagues (Wolpoff et al., 1981) report that Vi 256's squama is thin relative to that in the Krapina sample, although the difference is not significant. Vi 256's thickness (5.4 $\mathrm{mm}$ at the lateral eminence) is average for the Vindija sample (Wolpoff et al., 1981).

Vi 284 preserves a small section of temporal notch, running from a point just inferior to frontotemporale to the most posterior point of the frontomalar suture. It is preserved posteriorly as far as the posterior break, $14.5 \mathrm{~mm}$ from frontomalare temporale, and $26 \mathrm{~mm}$ behind the anterior supraorbital border (Wolpoff et al., 1981). The inferior margin of the temporal line is preserved. The surface of the fossa is one of the more rugose of the Vindija specimens. This reflects the general gracility of the temporal fossa in Vindija sample rather than a particularly rugose temporal fossa on Vi 284. Compared to Krapina specimens such as $\mathrm{Kr}$ 37.6, $\mathrm{Kr} 27 / 28$, and $\mathrm{Kr}$ 37.1, Vi 284's temporal fossa surface is fairly smooth. The frontomalar suture is preserved in its entirety, but none of the articulation with the sphenoid is preserved. Along with Vi 202, Vi 284 has the largest frontomalar suture when measured by area. This is of interest since the specimen, in some other respects (e.g., supraorbital torus morphology, see below), is fairly gracile. When viewed from the front, the sutural surface appears notched, with a distinct lateral overhang (Fig. 2). This overhang is distinct from that seen in Krapina 28, which exhibits a bulbous thickening above and lateral to frontomalare temporale that is a continuation of the torus. No such bulbous development is present on Vi 284. The overhang ust and is actually angled slightly more horizontally than the torus at this point.

Vi 284 preserves the right lateral part of the specimens, Vi 284 visibly has even less of a supratoral sulcus than the subadult Vi 279. In this manner, Vi 284-230-255-256 differs dramatically from most other Neandertals, whose supraorbital tori are much more projecting. Thickness at midorbit cannot be preciesely measured (contra Wolpoff et al., 1981) but it can be laterally (Table 3). 
Table 3

Supraorbital torus measurements for Vi 284-230-255-256, Krapina, Vindija, adult Neandertal, and adult Upper Paleolithic modern human samples

\begin{tabular}{|c|c|c|c|c|}
\hline & \multicolumn{2}{|c|}{ Thickness $^{\mathrm{a}}$} & \multicolumn{2}{|c|}{ Projection $^{\mathrm{a}}$} \\
\hline & Lateral & Midorbit & Lateral & Midorbit \\
\hline \multicolumn{5}{|l|}{ Krapina (adults) ${ }^{\mathrm{b}}$} \\
\hline Mean (mm) & 12.5 & 10.7 & 24.3 & 23.9 \\
\hline Bootstrap $95 \%$ C.I. for the mean $(\mathrm{mm})^{\mathrm{c}}$ & $11.8-14.1$ & $9.7-11.6$ & $23.5-25.2$ & $23.3-24.6$ \\
\hline$s(\mathrm{~mm})$ & 1.6 & 1.8 & 1.4 & 1.2 \\
\hline$n$ & 11 & 13 & 8 & 11 \\
\hline \multicolumn{5}{|l|}{ Neandertals (adult) ${ }^{\mathrm{d}}$} \\
\hline Mean (mm) & 12.2 & 10.6 & 24.2 & 22.6 \\
\hline Bootstrap $95 \%$ C.I. for the mean $(\mathrm{mm})^{\mathrm{c}}$ & $11.6-12.8$ & $10.0-11.2$ & $23.3-25.1$ & $21.5-23.7$ \\
\hline$s(\mathrm{~mm})$ & 1.6 & 1.7 & 2.2 & 2.9 \\
\hline$n$ & 26 & 28 & 22 & 26 \\
\hline \multicolumn{5}{|l|}{ Vindija (adults) ${ }^{\mathrm{e}}$} \\
\hline Mean (mm) & 10.6 & 8.9 & 22.1 & 18.9 \\
\hline Bootstrap $95 \%$ C.I. for the mean $(\mathrm{mm})^{\mathrm{c}}$ & $10.3-11.0$ & $8.3-9.5$ & $20.6-23.5$ & $16.9-21.0$ \\
\hline$s(\mathrm{~mm})$ & 0.5 & 0.8 & 1.8 & 2.9 \\
\hline$n$ & 5 & 6 & 5 & 6 \\
\hline Vi $284-230-255-256$ & 10.4 & $8.0\left(\right.$ ca. 8.6) ${ }^{\mathrm{f}}$ & 22.0 & 16.0 \\
\hline \multicolumn{5}{|l|}{ Upper Paleolithic Modern (adults) ${ }^{\mathrm{g}}$} \\
\hline Mean (mm) & 8.6 & 6.1 & 19.8 & 15.7 \\
\hline Bootstrap $95 \%$ C.I. for the mean $(\mathrm{mm})^{\mathrm{c}}$ & $7.7-9.4$ & $5.5-6.7$ & $17.8-21.8$ & $13.0-18.2$ \\
\hline$s(\mathrm{~mm})$ & 1.5 & 1.1 & 3.2 & 4.2 \\
\hline$n$ & 11 & 11 & 8 & 8 \\
\hline
\end{tabular}

${ }^{a}$ Measurements after Smith and Ranyard (1980). See text for descriptions. All measurements taken by FHS. Vindija and Krapina measurements successfully replicated by JCMA.

${ }^{\mathrm{b}}$ Krapina 3, 4, 6, 28, 37.1, 37.3, 37.4, 37.5, 37.6, 37.7, 37.8, 37.10, 37.11

${ }^{\mathrm{c}}$ Standard bootstrap confidence interval estimation (Manly, 1997) using 10,000 bootstrap samples. C.I. $=$ confidence interval.

${ }^{\mathrm{d}}$ Neandertal sample includes all adult Krapina and Vindija specimens (including Vi 284) in addition to Feldhofer 1, Forbes

Quarry, Guattari 1, La Chapelle, La Ferrassie 1, La Quina V, Sacopastore 2, St. Césaire, Spy I, and Spy II.

${ }^{\text {e} V}$ indija 202, 260, 261, 262, 284, 305.

f $8.0 \mathrm{~mm}$ is a minimum measurement due to preservation. Reconstructed midorbit thickness is approximately $8.6 \mathrm{~mm}$.

${ }^{g}$ Brno 2, Dolní Vestonice 3, Kelsterbach, Mladeć 1, 2, and 5, Paderborn, Pavlov, Podbaba, Vogelherd 1, and Vogelherd 2.

However, an absolute minimum estimate of midorbit thickness can be made that can establish which specimens Vi 284's torus is thicker than at midorbit. Lateral thickness is $10.4 \mathrm{~mm}$, while minimum midorbit thickness is $8 \mathrm{~mm}$ (the actual thickness was approximately $8.6 \mathrm{~mm})$. At the lateral point, thickness is $0.2 \mathrm{~mm}$ above the Vindija adult mean and $2.1 \mathrm{~mm}$ below the Krapina adult mean (Table 3; Wolpoff et al., 1981). At midorbit,
Vi 284 is thicker than $\mathrm{Kr} 1$ (juvenile), $\mathrm{Kr} 24$ (juvenile), Kr 37.5, Vi 227 (juvenile), Vi 260, and Vi 279 (subadult). Vi 284 and the little supratoral sulcus present on Vi 255 demonstrate that the browridge was not very projecting. Projection laterally is near the Vindija mean, but is well below that seen in other Neandertals (Table 3). Projection at midorbit is only $0.3 \mathrm{~mm}$ greater than the central European early Upper Paleolithic modern 
Table 4

Measurements of frontal sinus development in the Vindija and Krapina samples

\begin{tabular}{lccc}
\hline Specimen & $\begin{array}{c}\text { Midline to most lateral point of } \\
\text { sinus }(\mathrm{mm})\end{array}$ & $\begin{array}{c}\text { Upper hemifacial breadth } \\
(\mathrm{mm})^{\mathrm{a}}\end{array}$ & $\begin{array}{c}\text { Index of lateral sinus extent } \\
(\%)^{\mathrm{b}}\end{array}$ \\
\hline Vi 284-230-255-256 & 32 & 58.6 & 54.6 \\
Vi 224c & 23.4 & 54.5 & 43 \\
Vi $227^{\mathrm{c}}$ & 14.5 & 59.1 & 24.5 \\
Vi 261 & 35.3 & 58.1 & 60.8 \\
Vi 305 & 25.2 & - & - \\
Vi 308 & 23.7 & - & - \\
Kr 4 & 31.2 & 64.0 & 48.8 \\
Kr 23 & 37.5 & - & - \\
Kr $27 / 28$ & 44.8 & 61.2 & 73.1 \\
\hline
\end{tabular}

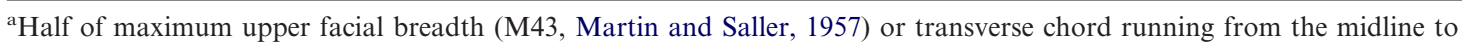
frontomalare temporale, if the specimen preserves only one side.

${ }^{\mathrm{b}}$ Index calculated as (distance from midline to lateral point of sinus $\div$ upper hemifacial breadth)*100.

'Subadult.

human mean and is well below that seen in other Neandertals, except the other Vindija specimens (Table 3). The overall thickness and projection of Vi 284-230-255-256's lateral supraorbital is very similar to that seen among central European Upper Paleolithic modern males such as Mladeč 5 and Předmosti 3 and is very reduced compared to Neandertals. Like these early modern humans, Vi 284's supraorbital was thin at midorbit relative to the condition laterally. However, the actual shape of Vi 284's lateral supraorbital element is different from that seen in modern humans. Robust modern humans exhibit straight, albeit slanted, lateral supraorbital segments that form the base of the flattened supraorbital trigon. Vi 284's lateral segment is slightly curved, and the posterolateral squamal piece, Vi 256, does not exhibit any flattening in the area where the posterosuperior portion of the supraorbital trigon should lie.

The posterior and right lateral walls and the midline septum of an expansive frontal sinus are preserved. Perhaps the best indication of the association of Vi 284 and 255 is the match of the lateral lobe of the right sinus between the two specimens. Four distinct lobes are apparent on the right side, while only parts of two are preserved on the left. Measured at the most lateral extent of the sinus, anterior wall thickness is approximately $4 \mathrm{~mm}$. The thickness of the sinus roof at the midline break, approximately $3.5 \mathrm{~mm}$ inferior to supraglabella, is $2.4 \mathrm{~mm}$. Medially the anterosuperior walls of the sinus are fairly thin. The tremendous thickness of the roof measured laterally may be an overestimate since only the lateralmost portion of the sinus is present. The roof's thickness laterally is $2.2 \mathrm{~mm}$. The anteroposterior dimension of the frontal sinus at its lateral break is $11 \mathrm{~mm}$, while its height is $7.8 \mathrm{~mm}$ (Wolpoff et al., 1981). The lateralmost point of the sinus lies $28.5 \mathrm{~mm}$ from frontomalare temporale (Wolpoff et al., 1981). With the association of Vi 284 and $\mathrm{Vi} 255$, the lateral-most point of the frontal sinus lies $32 \mathrm{~mm}$ from the midline. The relative lateral extent of the frontal sinuses of $\mathrm{Vi}$ 284-230-255-256's frontal sinus, as measured by an ad hoc index, lies between specimens Vi 224 (subadult) and Vi 261 (see Table 4). The sinus is limited to the torus and the supratoral sulcus.

In addition to a small portion of endocranial surface preserved on Vi 284, Vi 255 and 256 exhibit a large portion of the medial and superolateral endocranial surface. Vi 255's frontal crest is toruslike and is only moderately developed. The frontal crest splays out approximately $18 \mathrm{~mm}$ inferior to the superior break. Due to lack of cristae falx cerebri development, no sagittal sulcus is apparent. At an internal point vertically opposite supraglabella, the frontal crest is nearly $5 \mathrm{~mm}$ thick. Among the Krapina and Vindija remains, 
Table 5

Postorbital constriction among the Vindija and Krapina samples

\begin{tabular}{lccc}
\hline Specimen & $\begin{array}{c}\text { Maximum upper facial breadth } \\
(\mathrm{mm})\left(\mathrm{M} 43^{\mathrm{a}}\right)\end{array}$ & $\begin{array}{c}\text { Minimum frontal breadth (mm) } \\
\left(\mathrm{M} 9^{\mathrm{a}}\right)\end{array}$ & $\begin{array}{c}\text { Postorbital constriction }(\%) \\
\left(\mathrm{M} 9 / \mathrm{M} 43^{*} 100\right)\end{array}$ \\
\hline Vi 284-230-255-256 & $117.1^{\mathrm{c}}$ & $108.2^{\mathrm{c}}$ & 92.4 \\
Vi $224^{\mathrm{b}}$ & $108.9^{\mathrm{c}}$ & $100.2^{\mathrm{c}}$ & 92.0 \\
Vi $227^{\mathrm{b}}$ & $118.2^{\mathrm{c}}$ & - & - \\
Vi 261 & $116.2^{\mathrm{c}}$ & $100.6^{\mathrm{c}}$ & 86.6 \\
Kr 3 & $118.5^{\mathrm{c}}$ & 98.8 & 83.3 \\
Kr 4 & $128.1^{\mathrm{c}}$ & $103^{\mathrm{c}}$ & 80.4 \\
Kr 6 & $116.8^{\mathrm{c}}$ & 98.2 & 84.1 \\
Kr 27/28 & $122.4^{\mathrm{c}}$ & $99.1^{\mathrm{c}}$ & 81.0 \\
\hline
\end{tabular}

${ }^{\mathrm{a}}$ Following Martin and Saller (1957).

${ }^{\mathrm{c}}$ Values are single-side measurements multiplied by two.

${ }^{\text {bSubadult. }}$

only Vi 305 exhibits a more robust frontal crest. Vi 255 's crest is remarkably similar in form to that of Vi 261/275, although Vi 255's is more developed toward the right while Vi 275 's is the opposite. Vi 275 also exhibits more cresting than Vi 255. The parietal specimen, Vi 230, possesses impressions for the middle meningeal artery. No arachnoid depressions are present on any of the Vindija specimens.

The combination of Vi 284, Vi 255, Vi 256, and Vi 230 (Vi 284-230-255-256) permits assessment of many aspects of this individual's vault anatomy that were not accessible before the fossils were associated (e.g., Wolpoff et al., 1981). Mediolateral frontal dimensions made to the midline now supplement those from Vi 224 (subadult) and Vi 261 (Table 5). Vi 284-230-255-256 exhibits markedly less postorbital constriction than any of the Vindija or Krapina specimens, except the subadult Vi 224. Furthermore, the reconstructed vault is broader relative to the upper face and higher than any of the adult Krapina crania. The vault height and curvature of the frontal squama are similar to those seen on Spy 2. Yet, Vi 284-230255-256's lateral supraorbital segment is significantly thinner and somewhat less projecting than Spy 2's.

Vi 284-230-255-256 appears more similar to early anatomically modern humans than do any of the Krapina specimens. This may reflect the evolutionary intermediacy of the Vindija hominids as posited by some authors (Smith and Ranyard, 1980; Wolpoff et al., 1981; Smith, 1982, 1984, 1994; Frayer et al., 1993). Vi 284's modern features (e.g., supraorbital gracility, reduced postorbital constriction, and rounded, high vault) cannot be explained by subadult age at death. The lateral segment of the torus, although thinner and less projecting than many adult Neandertals, exhibits a well-developed anterior face. A well-developed anterior face on the lateral supraorbital segment is characteristic of adult Neandertals but not of adolescents (Ahern and Smith, in press). The frontal sinus is laterally extensive, unlike in subadults. Furthermore, vermiculate bone is present across the entire anterior surface and extends superiorly onto the medial segment as well as onto the lateralmost portion of the lateral segment. The pattern is moderate, being much less distinct than in $\mathrm{Kr} 27 / 28$ and more like the subtlety of $\mathrm{Kr} 37.5$ 's vermiculate pattern. Vi 284's pattern of vermiculate bone is commensurate with an adult age at death (Smith and Ranyard, 1980). Thus, Vi 284230-255-256 is clearly an adult. However, cranial anatomy, including that of the supraorbital region, can change significantly during adulthood (Behrents, 1985; Israel, 1968, 1971, 1973, 1977; Russell, 1983; Hofbauer et al., 2003). In a recent quantitative analysis of adult age- and sex-related variation in the Krapina and Vindija supraorbital samples, neither the adult age (young vs. old adult) nor the sex of Vi 284-230-255-256 could be 


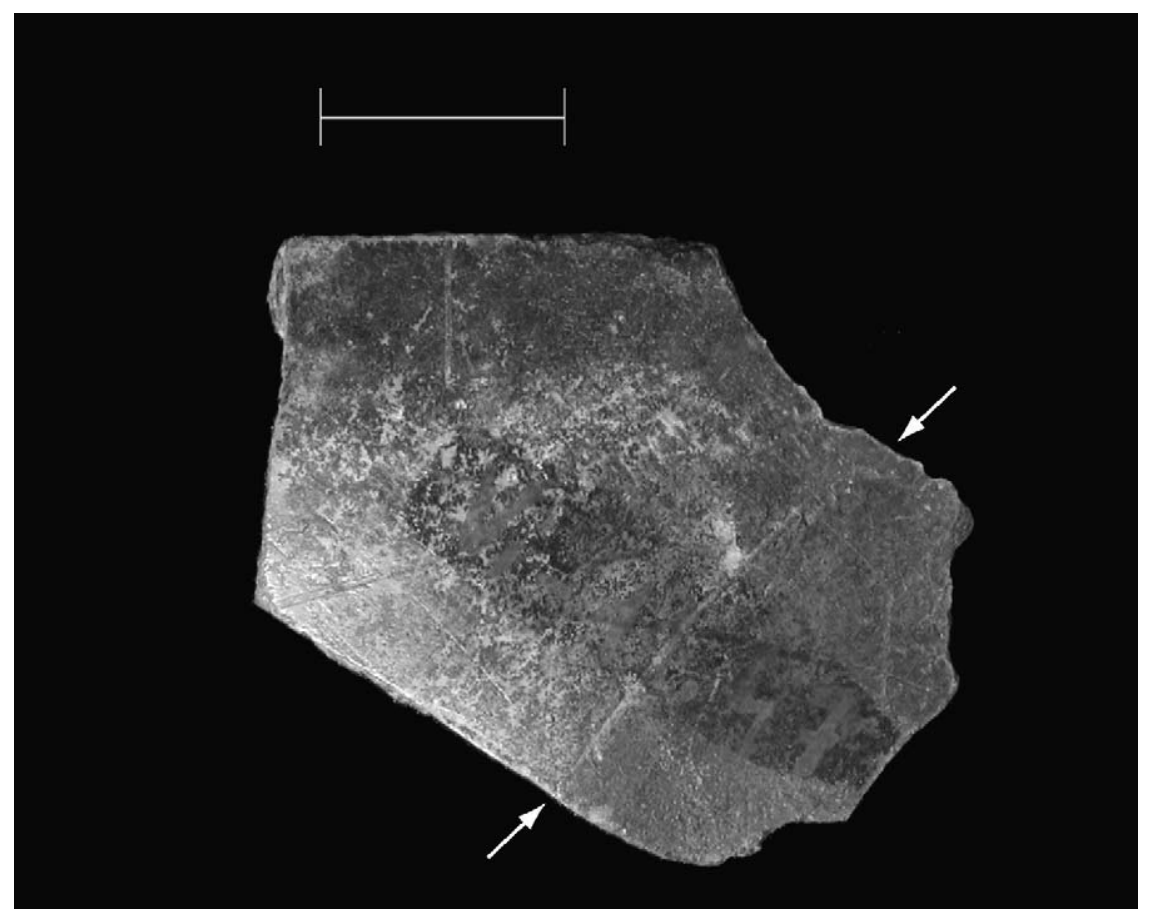

Fig. 5. External aspect of Vindija 11.47, a frontal squama fragment. Arrows mark the temporal line. Scale is $1 \mathrm{~cm}$.

determined (Ahern, 1998, 1999). Even if Vi284230-255-256 represents a young adult female, the fossil is still gracile and modernlike for a Neandertal. Purported young adult females from Krapina, Kr 3 and $\operatorname{Kr} 6$ (Ahern, 1998), and other purported adult female Neandertals such as Forbes Quarry, La Quina 5, and Spy 2, exhibit greater postorbital constriction, lower vaults, and larger supraorbital tori than does Vi 284-230-255-256.

\section{New cranial remains}

\section{Vi 11.47: frontal fragment (Figs. 5 and 6): $G$}

Vi 11.47 consists of a small section of frontal squama with temporal fossa. The larger portion of the specimen (when divided by the temporal line) appears to be temporal fossa based on how much thicker it is than the other side. Furthermore, the temporal line has a more distinct margin on the smaller preserved half. On the two well preserved Krapina fragments that include stephanion $(\mathrm{Kr}$ $31.2, \mathrm{Kr} 31.4$ ), this temporal line shelving is found only on the superior (non-temporal fossa) side of the squama. Vault thickness below the temporal line is much greater on the anterior end of the specimen, which indicates that it is from the right side. Given the lack of angulation between the temporal fossa and the surface above the temporal line, it is probably from the posterior part of the frontal, albeit anterior to stephanion (no coronal suture is present). Thickness of the squama along the temporal line is $4.7 \mathrm{~mm}$ posteriorly, and 5.7 $\mathrm{mm}$ anteriorly. Maximum thickness of the squama above is $4.9 \mathrm{~mm}$, while its minimum thickness is $3.6 \mathrm{~mm}$. Maximum thickness below the temporal line is $5.6 \mathrm{~mm}$, while minimum thickness is $4.5 \mathrm{~mm}$. The temporal line itself is very smooth, much smoother than any Krapina specimen, and the specimen is not nearly as angled and shelved as $\mathrm{Kr}$ 31.2 and $\mathrm{Kr} 31.4$.

\section{Vi 11.48: frontal fragment (Figs. 7 and 8)}

Exact provenience is unknown for this specimen although it is likely from unit $G$ or older. Its coloring and density are very similar to the 


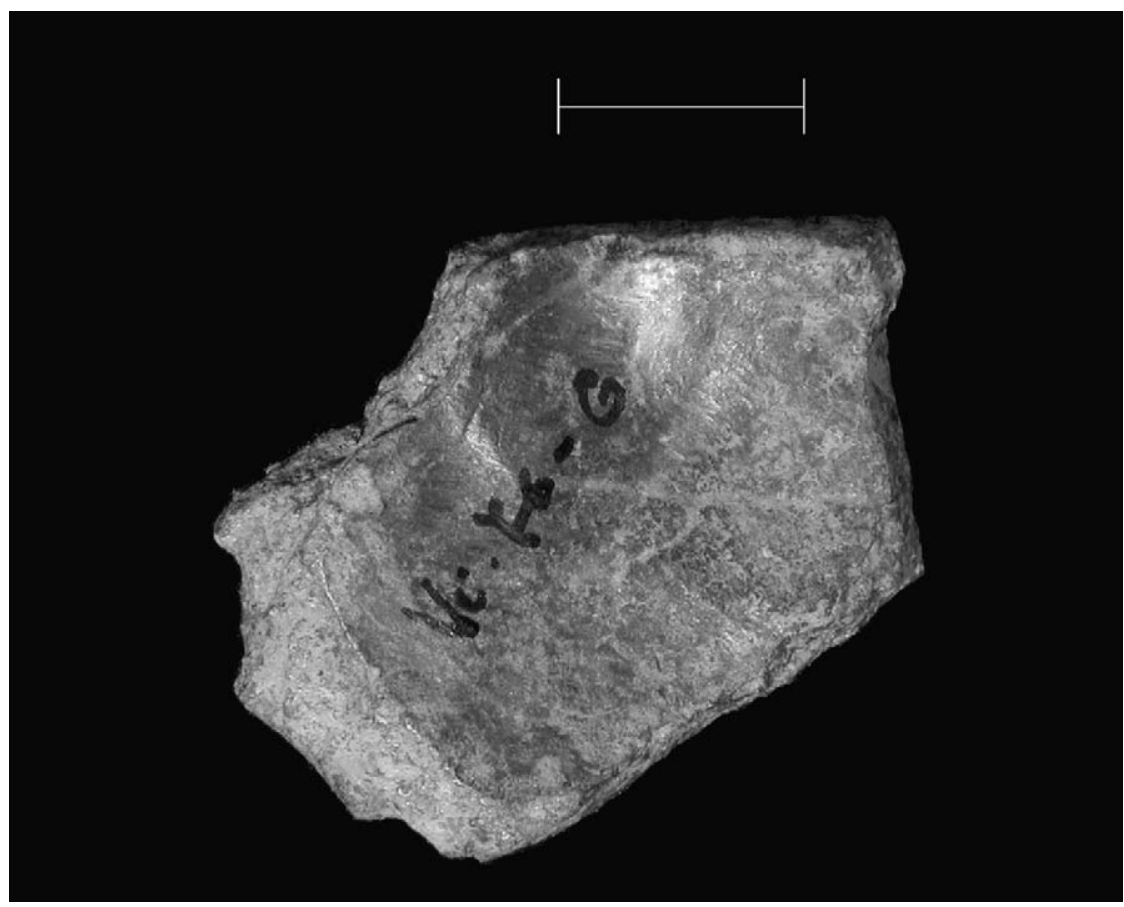

Fig. 6. Internal aspect of Vindija 11.47, a frontal squama fragment with temporal line. Scale is $1 \mathrm{~cm}$.

hominid fossils from units $G$ and I and are very different from the late Upper Paleolithic bones from unit D. Vi 11.48 is a posterior frontal squama fragment that measures $53 \mathrm{~mm}$ long by $36.3 \mathrm{~mm}$ broad. It preserves $18.8 \mathrm{~mm}$ of coronal suture. It is frontal, not parietal, since there are no grooves for meningeal vessels. Thickness ranges from $5.7 \mathrm{~mm}$ along the inferior break to $4.7 \mathrm{~mm}$ along the coronal suture. The specimen is marked externally by one small vascular groove and one larger one with multiple branches. The larger one originates $30.5 \mathrm{~mm}$ inferior to the coronal suture and $2.4 \mathrm{~mm}$ from the break. It runs superiorly and its largest branch terminates $9.7 \mathrm{~mm}$ inferior to the coronal suture. A series of parallel striations run diagonally (from left superiorly to right inferiorly) across the squamal surface. These appear to be post-mortem in origin.

\section{Vi 11.49: frontal fragment (Figs. 9 and 10): $G_{3}$}

Vi 11.49 is a piece of frontal squama with a short $(15.5 \mathrm{~mm})$ section of non-rugose, but but- tressed temporal line. The temporal fossa and squama above it are highly angled relative to each other, suggesting that the fragment is from an anterior portion of the frontal bone. The endocranial surface has a $2 \mathrm{~mm}$ diameter hole that appears to have been drilled since excavation. A similar hole is found on Vi 11.52.

\section{Vi 11.52: right partial mandibular ramus (Figs. 11 and 12): I}

Vi 11.52 is a portion of a right posterior mandibular ramus. It was originally excavated from unit $I$ in 1975. Maximum height of the fossil is $54.9 \mathrm{~mm}$, and its maximum anteroposterior width is $19.1 \mathrm{~mm}$. A maximum breadth of $8.1 \mathrm{~mm}$ lies near the superior break (at the base of the condylar process), and breadth of the specimen at the medial pterygoid tubercle is $5.2 \mathrm{~mm}$. Superiorly, the specimen is broken just below the mandibular condyle. Inferiorly, the posteroinferior margin is broken just superior to the gonial angle. The anterior portion of the mandibular ramus is 


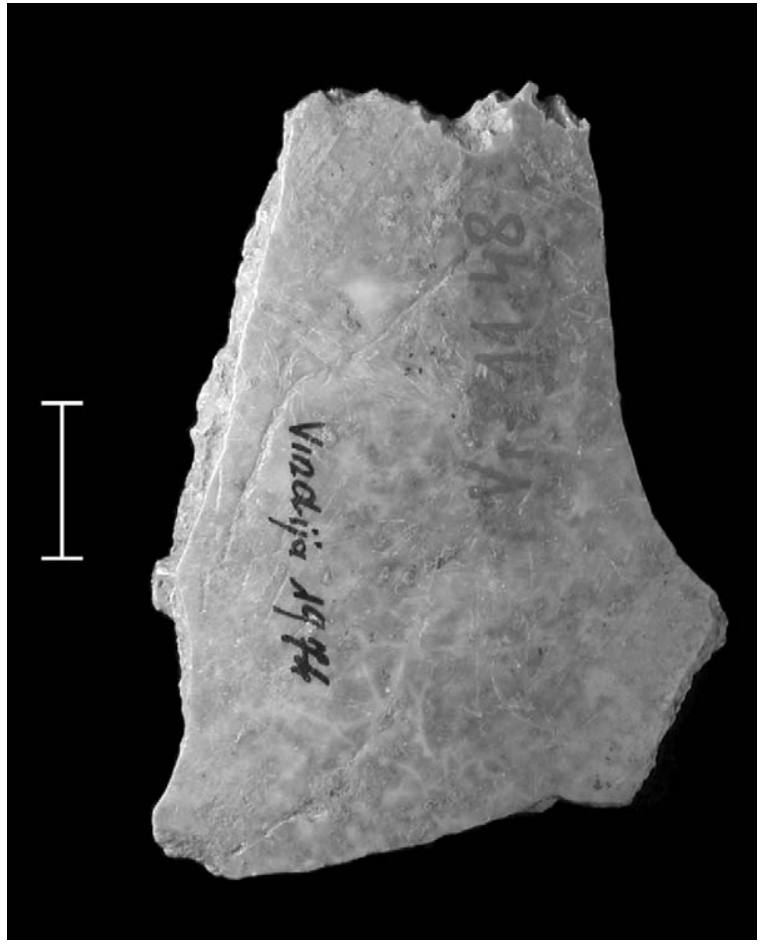

Fig. 7. External aspect of the posterior frontal squama, Vindija 11.48. Scale is $1 \mathrm{~cm}$.

missing. The internal surface bears the attachment area for the medial pterygoid muscle, and the superior area of attachment forms a distinct medial pterygoid tubercle. Medial pterygoid tubercles are also found on Vi 207 from level $\mathrm{G}_{1}$ and Vi 226 from level $\mathrm{G}_{3}$. Vi 11.52's medial pterygoid tubercle is more distinct than that of Vi 207 but less so than that of Vi 226. According to Rak and colleagues (Rak et al., 1994), the medial pterygoid tubercle is a derived Neandertal feature. Thus, its presence on Vi 11.52 strongly suggests that this specimen is Neandertal. The medial surface has a $2 \mathrm{~mm}$ diameter hole that appears to have been drilled since excavation. A similar hole is found on $\mathrm{Vi}$ 11.49 .

\section{New postcranial remains}

Vi 13.7: left partial ilium (Figs. 13 and 14): $G_{3}$

Vindija 13.7 is a portion of left hominid innominate bone from level $\mathrm{G}_{3}$. This specimen preserves most of the greater sciatic notch, the superior

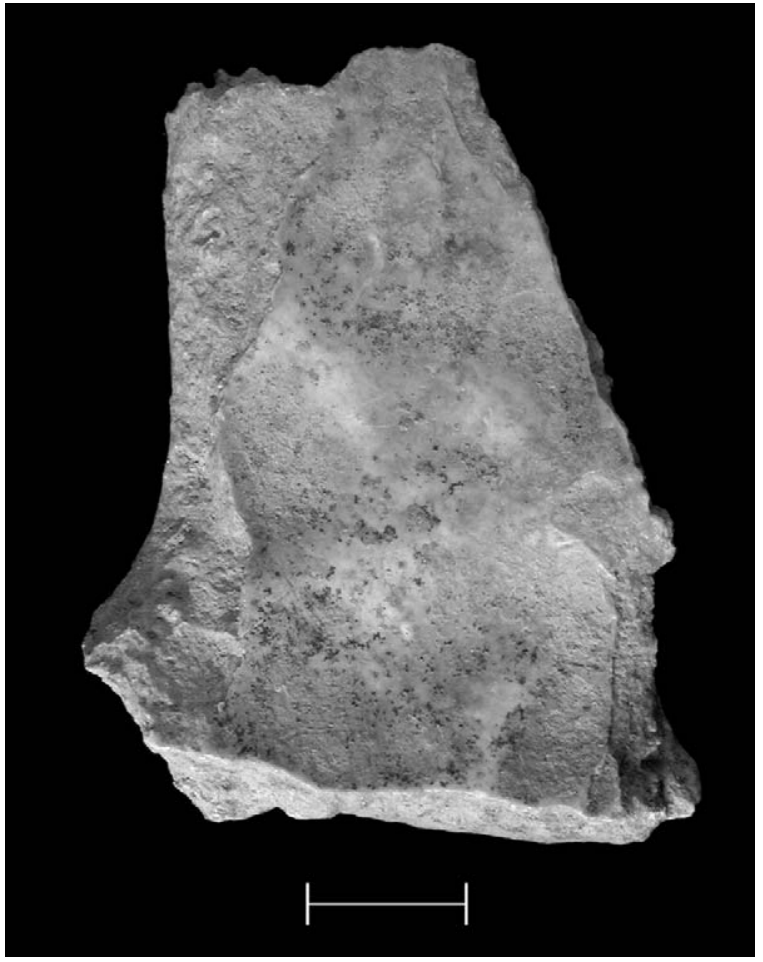

Fig. 8. Internal aspect of the posterior frontal squama piece, Vindija 11.48 . Scale is $1 \mathrm{~cm}$.

portion of acetabulum, and a small portion of sacroiliac articular surface. The maximum nonanatomical width of the specimen is $90 \mathrm{~mm}$ and runs from the posterior break of the articular surface to anterior break of the acetabular surface. The specimen's maximum non-anatomical height is $60.4 \mathrm{~mm}$ and runs between the superior break of the iliac blade (approximately $30 \%$ of the height of the iliac blade is preserved) and the inferior break of the anterior margin of the greater sciatic notch. Maximum thickness is $28.9 \mathrm{~mm}$ and spans the preserved acetabular surface, mediolaterally. Approximately $32 \mathrm{~mm}^{2}$ of lunate surface, $5 \mathrm{~mm}^{2}$ of the acetabular fossa, and $21.5 \mathrm{~mm}^{2}$ of the sacral articular surfaces are preserved.

The Vindija specimen's greater sciatic notch is broader and shallower than that of Feldhofer 1 and Krapina 207. Furthermore, although only the inferior portion of the Vindija specimen's iliac blade is preserved, it appears to be more flared. 


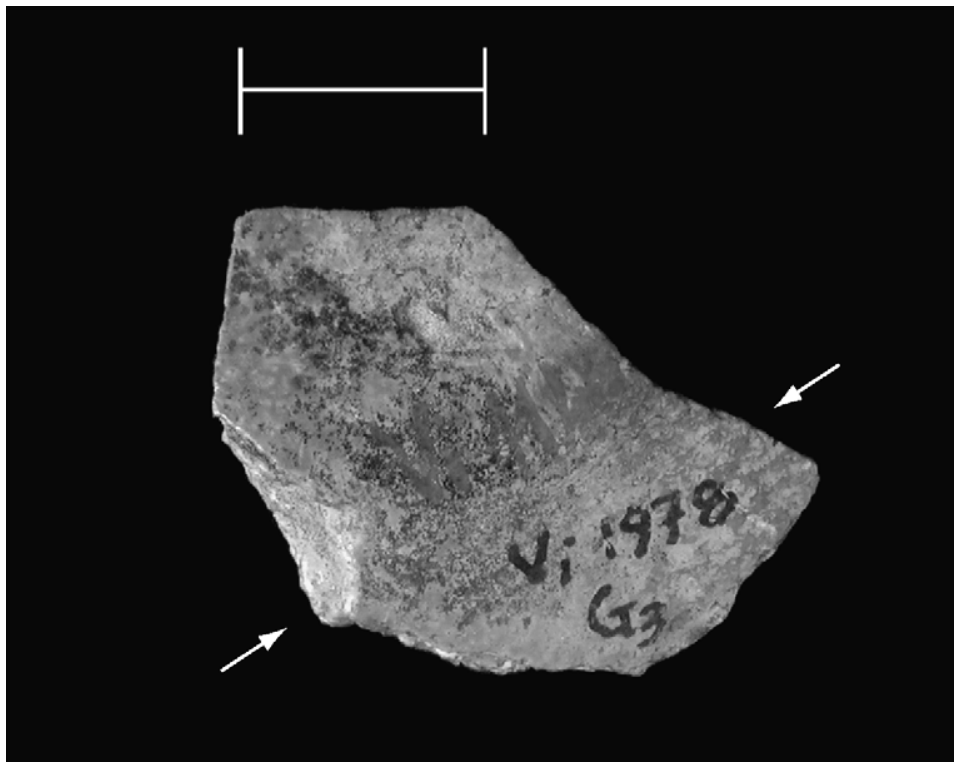

Fig. 9. External aspect of Vindija 11.49, a fragment of frontal squama preserving a portion of the temporal line (marked by the arrows). Scale is $1 \mathrm{~cm}$.

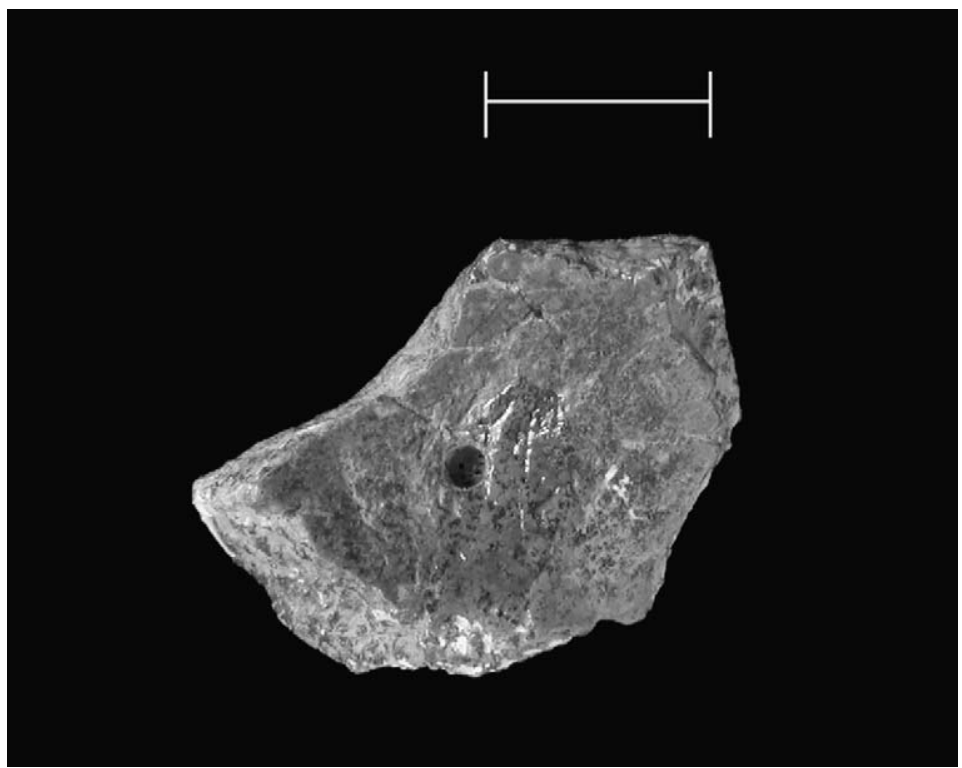

Fig. 10. Internal aspect of Vindija 11.49, a frontal squama fragment preserving a portion of the temporal line. Scale is $1 \mathrm{~cm}$.

These two points of difference might suggest that the Vindija specimen is that of a female. However, Krapina 209, a likely female Neandertal, has a much broader greater sciatic notch than Vi 13.7. Additionally, male Caucasoids often exhibit broad greater sciatic notches (Flores, 2001). The most 


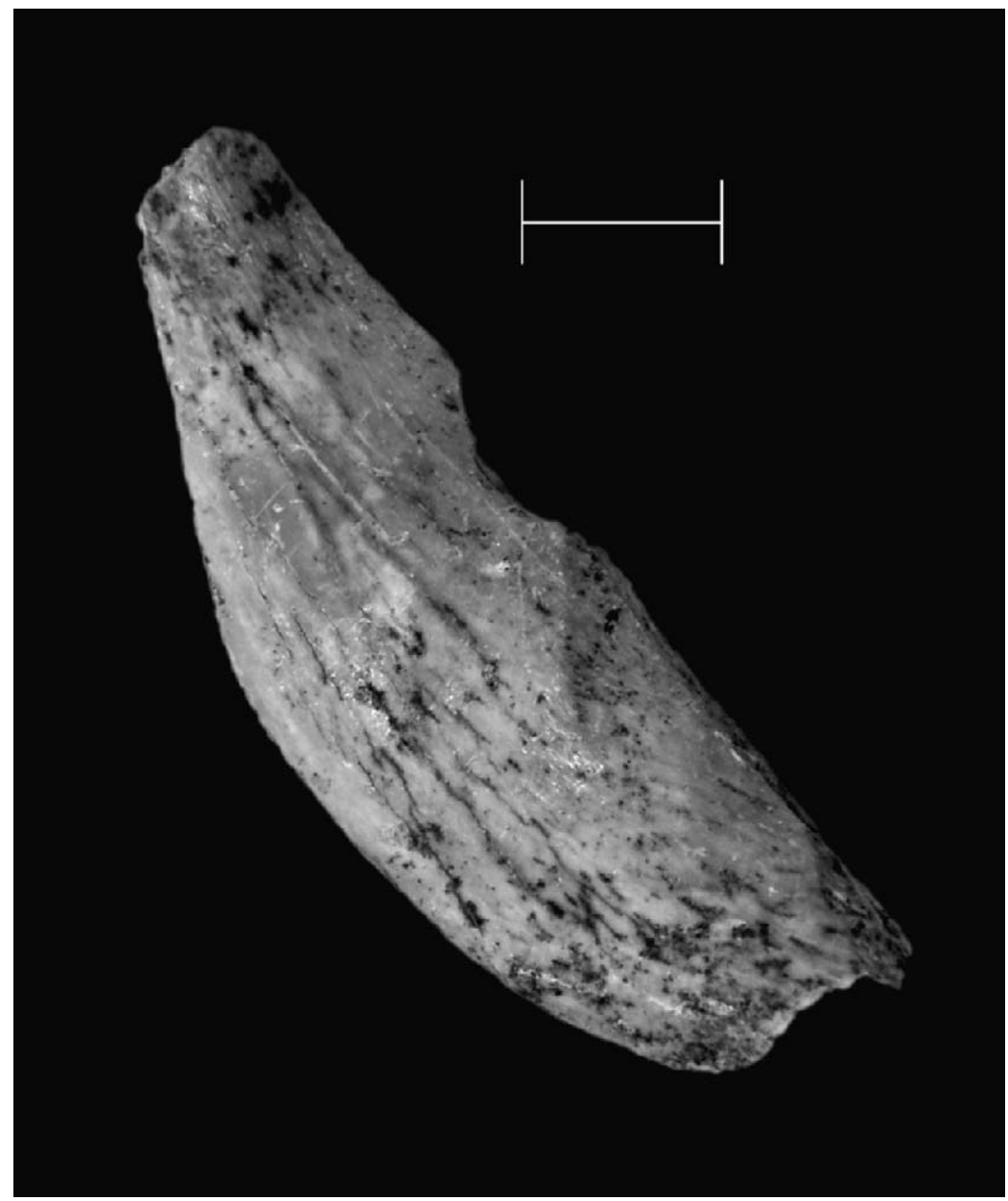

Fig. 11. Lateral view of Vindija 11.52, a fragment of a right mandibular ramus. Scale is $1 \mathrm{~cm}$.

posterior point of the superior acetabular notch is preserved. Distance from the posterior terminus of the acetabular notch to maximum height of sciatic notch is $31 \mathrm{~mm}$. This is small compared to Feldhofer $1(44.7 \mathrm{~mm}$, cast $)$ and to a sample of recent Euro-Americans (mean $=40.3 \mathrm{~mm}, s=4.7$ $\mathrm{mm}, n=9)$, but is similar to Krapina 207 (33 mm). Unfortunately, it is unclear whether or not this measurement reflects the actual distance from the acetabulum to the greater sciatic notch, since the form of the acetabular notch is variable. A nutrient foramen is located approximately $8 \mathrm{~mm}$ posterior to the maximum height/depth of the sciatic notch.
Vi 13.8: left radial shaft (Figs. 15-17): $G_{1}$

This specimen is a $10.4 \mathrm{~cm}$ long fragment preserving the radial tuberosity (Fig. 15). Since the proximal break is approximately $4 \mathrm{~mm}$ above the radial tuberosity, it is not possible to determine whether the radial head had fused with the diaphysis. The distal break is approximately at midshaft. Shaft circumference at the distal break is $38 \mathrm{~mm}$. This is the same value as midshaft circumference for the female Neandertal La Ferrassie 2 and is larger than that of Tabun I (33 mm). Based on data from Wolpoff (1999), the Neandertal mean midshaft circumference is $40.8 \mathrm{~mm}(s=4.3, n=11)$. The mean for a sample of modern human radii is 


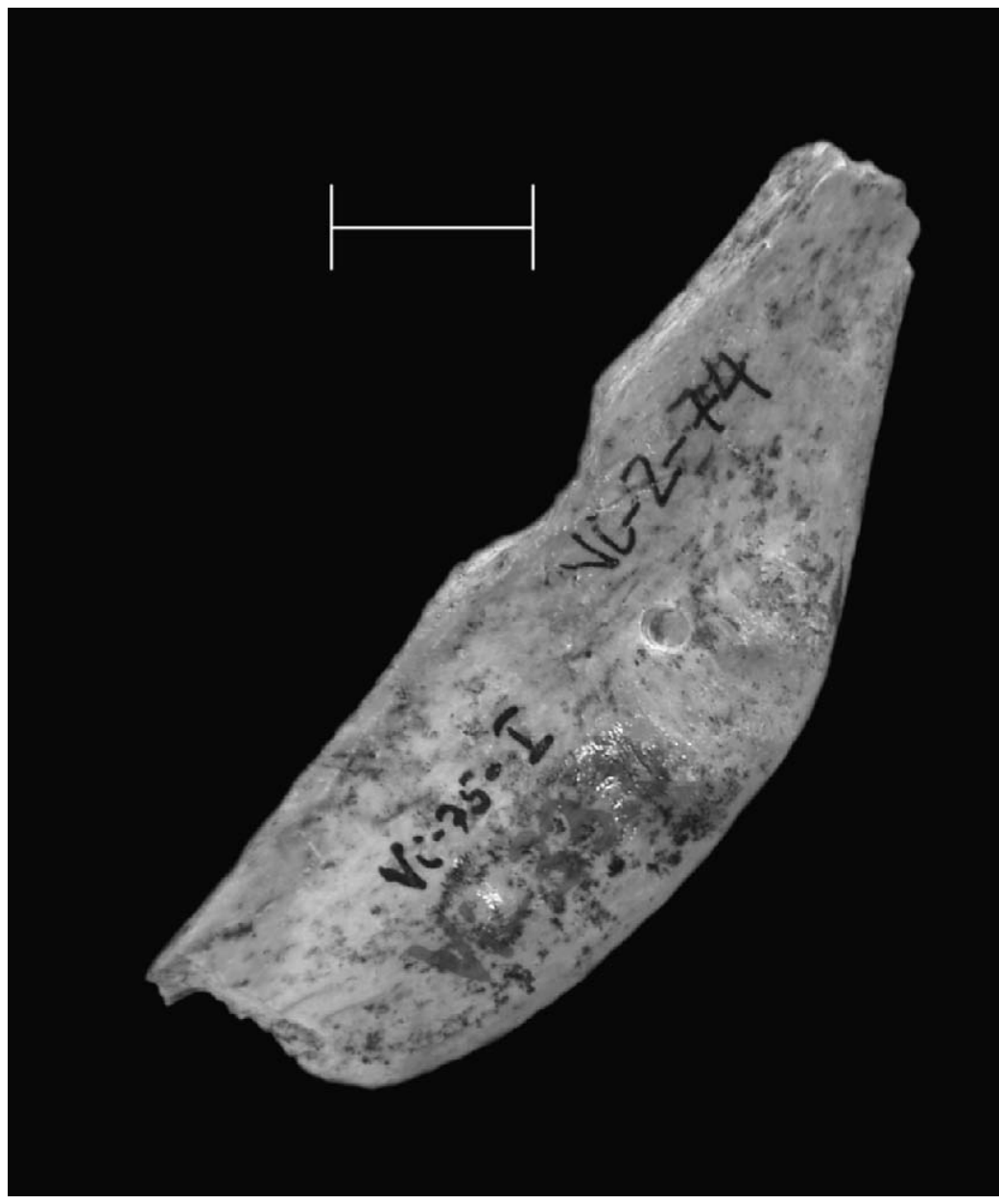

Fig. 12. Medial view of the partial right mandibular ramus, Vindija 11.52 . Scale is $1 \mathrm{~cm}$.

$38.5 \mathrm{~mm}(s=5.3, n=21)$. Vi 13.8's measurement falls on the low end of the $95 \%$ standard bootstrap confidence interval for the Neandertal mean (37.9$44.1 \mathrm{~mm}$ ), and falls well within the $95 \%$ bootstrap confidence interval for the modern human mean (36.3-40.7 $\mathrm{mm})$. The $95 \%$ bootstrap confidence level for the Neandertal male mean- $2 s$ is $36.3 \mathrm{~mm}$, while the $95 \%$ bootstrap confidence level for the Neandertal female mean $+2 s$ is $47.8 \mathrm{~mm}$. Thus, Vi 13.8 falls into the androgynous range for Neandertals in terms of its midshaft circumference. Anteroposterior thickness just superior to the radial tuberosity is $11.5 \mathrm{~mm}$, and just inferior to the tuberosity it is $11.6 \mathrm{~mm}$.
Mediolateral breadth superior to the tuberosity is $11.6 \mathrm{~mm}$ and it is $11.5 \mathrm{~mm}$ just below tuberosity. These measurements are small compared to the Spy left radius and a sample of modern Homo sapiens $(n=31)$.

The maximum medial projection of the tuberosity is posterosuperior, although much of the base of the tuberosity lies anterior to the interosseus crest (see Fig. 17). The interosseus crest falls within the middle third of the tuberosity, close to the posterior third. A tuberosity whose middle third is in line with the interosseus crest is medially oriented (Trinkaus and Churchill, 1988). According to Trinkaus and Churchill (1988), this orientation 


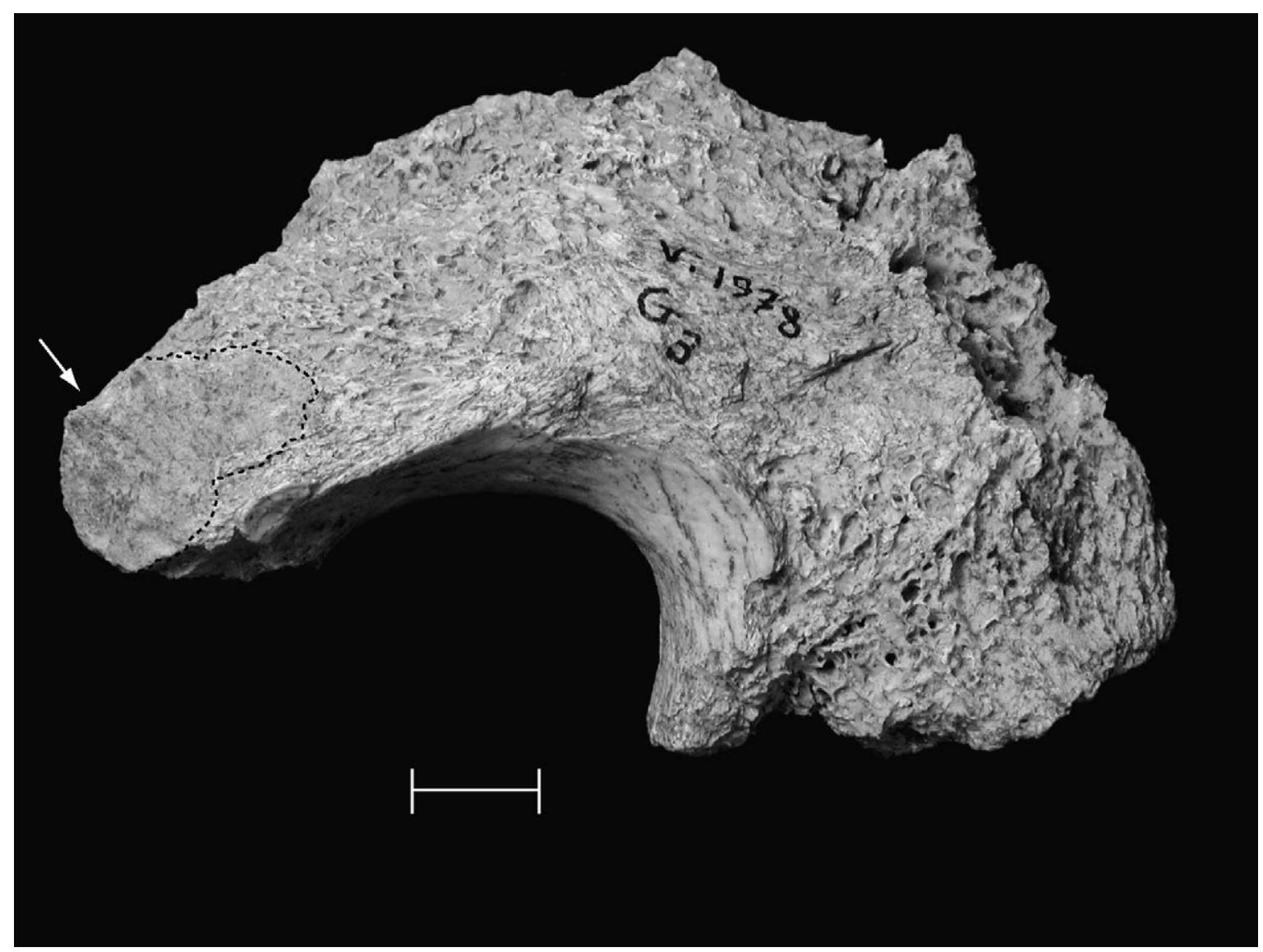

Fig. 13. Anteromedial aspect of the partial left ilium, Vindija 13.7. Arrow points to the sacral articular surface (outlined by the dashed line). Scale is $1 \mathrm{~cm}$.

is found among $76.5 \%$ of Neandertals $(n=17)$, but only among $11.2 \%$ of modern Euro-Americans $(n=76)$. Churchill (1994), using a different coding for this trait, reported that medial or posteromedial orientation is not found among early Upper Paleolithic modern humans. The more medially oriented the radial tuberosity, the greater is the mechanical advantage of biceps brachii in supination (Trinkaus and Churchill, 1988). Trinkaus and Churchill (1988) suggest that a medially oriented radial tuberosity is primitive for hominids. Carretero and colleagues (Carretero et al., 1999) suggest that Neandertals have reverted to the primitive condition after having evolved from archaics, such as those represented by Sima de los Huesos and Gran Dolina, which had already gained the derived anteromedial radial tuberosity orientation. Yet, given this feature's variability among recent humans (Trinkaus and Churchill, 1988; Churchill, 1994) and the untested effect of habitual stress on its expression, its phylogenetic significance should not be overstated. A medial orientation of Vi 13.8's radial tuberosity is suggestive, but not conclusive, of Neandertal affinities for this specimen.

The radial neck shaft is fairly round in cross section and is similar to Neandertals in this respect, yet the midshaft is slightly more anteroposteriorly flattened than what is observed among the Neandertal radii from Feldhofer, Spy, and Krapina. The shaft is significantly more curved than any observed in a sample of recent 


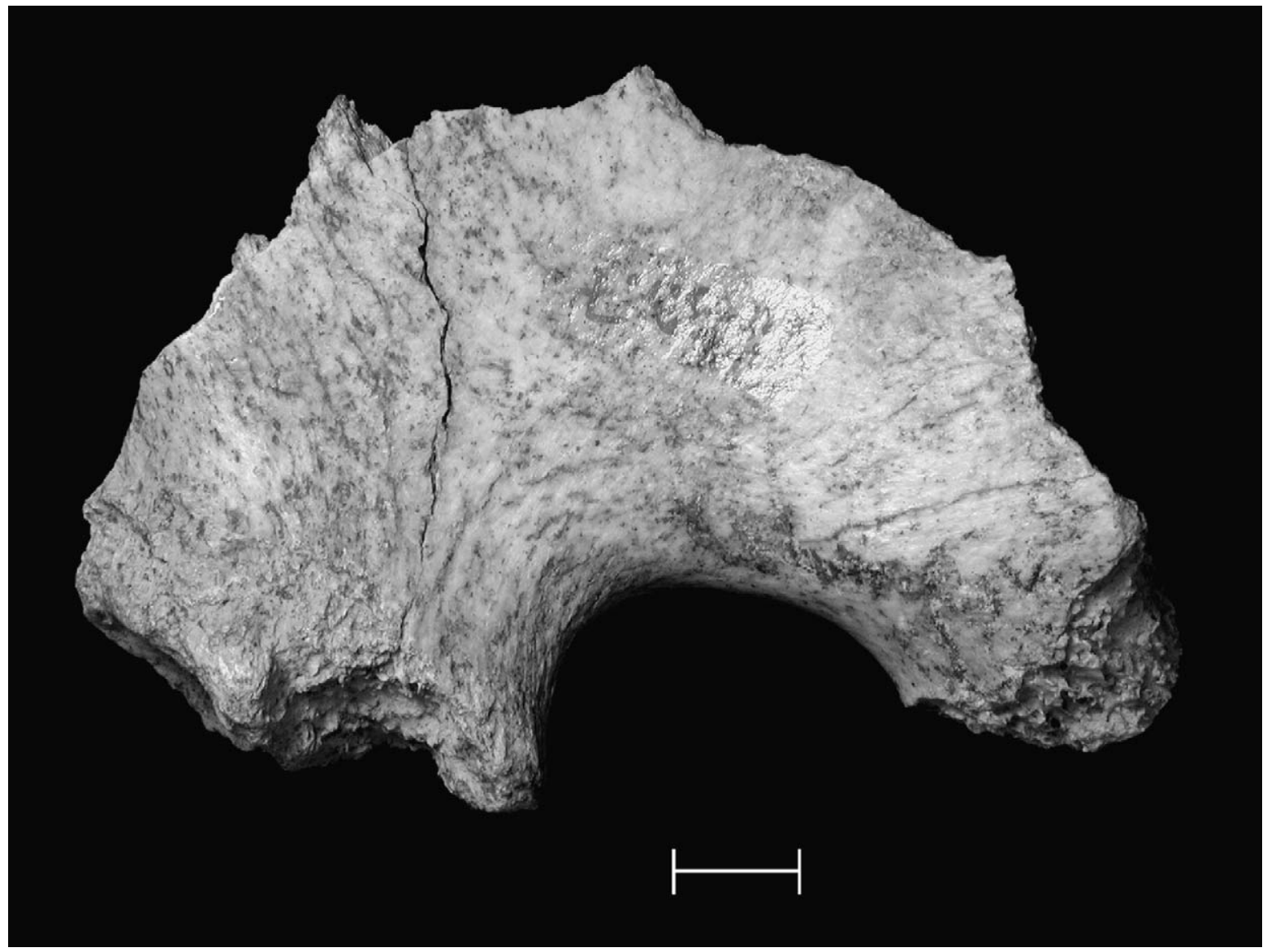

Fig. 14. Posterolateral aspect of the partial left ilium, Vindija 13.7. Scale is $1 \mathrm{~cm}$.

humans $(n=33)$ and is nearly as curved as the radii from Feldhofer 1 and Spy (Table 6). Vi 13.8 's radial tuberosity orientation, shaft curvature, and, to a certain degree, its shaft crosssectional geometry suggest that the fossil represents a Neandertal. However, the overlap between Neandertals and modern humans in these traits is significant (Trinkaus and Churchill, 1988; Pearson and Grine, 1997), making the Neandertal designation for this Vindija radius equivocal.

No provenience is recorded for the specimen, but reddish clay is embedded in both broken ends as well as in some deeper topography along the shaft. This reddish clay is only characteristic of bones recovered from level $\mathrm{G}_{1}$. Vi 13.8's anatomy, although not conclusive, is suggestive of the presence of Neandertals in $\mathrm{G}_{1}$, as posited previously (Karavanić and Smith, 1998; Smith and Ahern, 1994; Smith et al., 1999).

\section{Vi 13.10: right scapular fragment (Figs. 18 and 19): I}

Vi 13.10 was excavated in 1975 from unit I. It preserves the inferior angle of a right scapula. Maximum length of the specimen is $64.4 \mathrm{~mm}$ and the maximum height is $26 \mathrm{~mm}$. The inferior portion of the infraspinatus fossa is preserved and is well excavated. The margin of the inferior angle is thick and robust. Border thickness at the angle point is $9.6 \mathrm{~mm}$. Although overall axillary border anatomy is difficult to assess from this portion of 


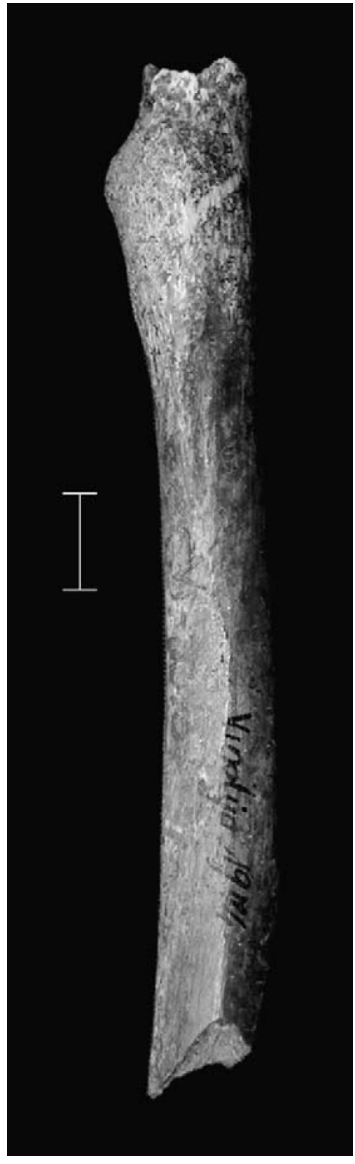

Fig. 15. Anterior view of the left proximal radial shaft, Vindija 13.8. Scale is $1 \mathrm{~cm}$.

the scapula, the preserved portion of the sulcus is dorsally located. Dorsal scapular sulci are found in $65 \%$ of Neandertals, $17 \%$ of the earliest post-Neandertal Europeans, and $1 \%$ of living Europeans (Frayer, 1992; see Churchill, 1994 for a different coding but similar frequencies). Smith (1976) and Trinkaus $(1977,1983)$ posit that the phylogenetic significance of this characteristic is unclear, and Trinkaus (1977) suggests that a dorsal sulcus implies a powerful $M$. teres minor.

\section{Revision to the interpretation of the $\mathbf{G}_{3}$ Mousterian technology}

The Vindija hominids and their association with industries of the Middle (Level $\mathrm{G}_{3}$ ) and Upper

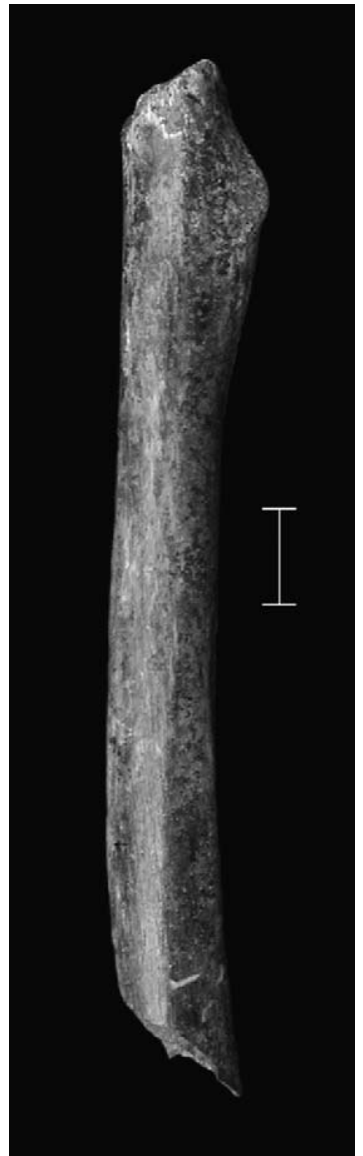

Fig. 16. Posterior view of the left proximal radial shaft, Vindija 13.8. Scale is $1 \mathrm{~cm}$.

Paleolithic $\left(G_{1}, F_{d}, D\right)$ pose one of the most interesting problems of this site. Particularly puzzling is the association of Neandertal fossils with an Aurignacianlike assemblage in at least one stratigraphic level. The hominid fossils are separated stratigraphically into four groups (Smith, 1982; Smith and Ahern, 1994). The first group consists of remains of Neandertals from level $\mathrm{G}_{3}$ associated with late Mousterian. The second group consists of Neandertals from level $G_{1}$ associated with Mousterian and Upper Paleolithic lithic artifacts and Upper Paleolithic bone points (1 split-based, 3 Mladec points, and several bone point fragments). Three isolated teeth from Aurignacianlike level $\mathrm{F}_{\mathrm{d}}$, and two articulating posterior parietal fragments from the contact of 


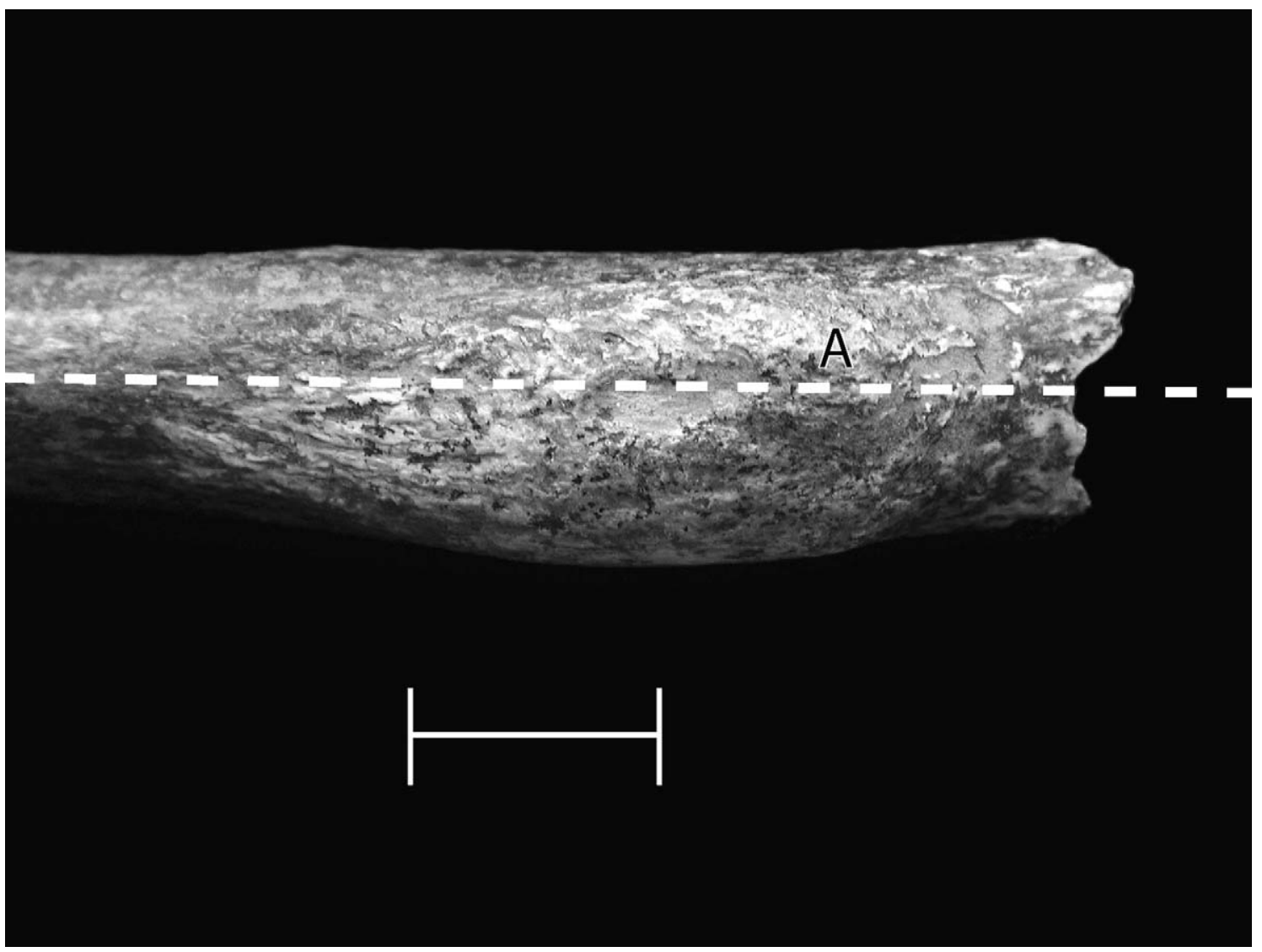

Fig. 17. Medial view of the proximal end of the radial shaft, Vindija 13.8. "A" denotes the position of maximum tuberosity development. The dashed line marks the plane of the interosseus crest. The interosseus crest falls in the middle third of the tuberosity, albeit close to the beginning of the posterior third. This is Position 3 (Trinkaus and Churchill, 1988), which is most common among Neandertals. Scale is $1 \mathrm{~cm}$.

levels $F_{d}$ and $F_{d / d}$ form the third group. The fossils of the third group exhibit a mosaic of Neandertal and modern anatomy. The fourth group comprises finds of modern $H$. sapiens from Epigravettian unit D.

Technological analysis and raw material of the $G_{3}$ lithic assemblage

While the industries from all levels of Vindija cave were preliminarily published (Malez, 1975), the lithic artifacts and bone objects from the Upper Paleolithic levels (Karavanić, 1995) and late Mousterian stratigraphic levels $G_{3}, G_{2 / 3}, G_{2}, G_{1} /$ $\mathrm{G}_{2}, \mathrm{G}_{/ \mathrm{g}}$ (Karavanić and Smith, 1998) have been analyzed in much more detail. We reanalyzed lithics from level $\mathrm{G}_{3}$ in order to study separately the technology of two main groups of raw material (quartz and related materials; chert/tuff), because we noted that the morphology of $\mathrm{G}_{3}$ debitage depended on which raw materials were knapped. This separation was not performed in the previous analysis by Karavanić and Smith (1998). Our analysis also differed from that of Karavanic and Smith (1998) in that we compared the $\mathrm{G}_{3}$ assemblage with earlier Middle Paleolithic and later Upper Paleolithic assemblages from Vindija in terms of raw materials used for tool production.

Blaser and colleagues (Blaser et al., 2002) classified the Vindija lithics into the following categories 
Table 6

Radial shaft curvature

\begin{tabular}{|c|c|}
\hline Specimen/fossil & Area of curvature $\left(\mathrm{mm}^{2}\right)^{a}$ \\
\hline Vi 13.8 & 36.8 \\
\hline Feldhofer 1 (cast) & 41.3 \\
\hline Spy 1 (cast) & 61.8 \\
\hline \multicolumn{2}{|l|}{ Modern H. sapiens ${ }^{\mathrm{b}}$} \\
\hline Mean & 10.1 \\
\hline Bootstrap $95 \%$ C.I. for mean ${ }^{\mathrm{c}}$ & $7.0-13.5$ \\
\hline$s^{\mathrm{d}}$ & 9.6 \\
\hline$n$ & 33 \\
\hline
\end{tabular}

aThe area of curvature is measured as the area between two lines with common endpoints: 1) the curved line follows the midline of the shaft as determined at $1 \mathrm{~cm}$ intervals and 2) the straight line, is a chord connecting the two midline endpoints used in determination of the curved line. Since Vi 13.8 preserves only a segment of the shaft, the lines and area of curve measurement were made for only the same portions of the shaft on the other radii. The portion of the shaft used did not include the radial tuberosity.

bample composition: 19 males, 7 females, 7 sex indeterminate; 10 Amerindian (Northwest Plains), 13 Euro-American (Northwest Plains), 10 indeterminate population (Northwest Plains Amerindian or Euro-American).

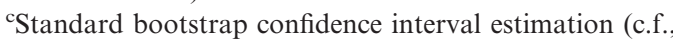
Manly, 1997) with 10,000 bootstrap samples. C.I.=confidence interval.

${ }^{\mathrm{d}}$ The distribution is right skewed and, thus, the standard deviation is not the best statistic to describe the spread for this variable (i.e., the mean minus one standard deviation yields a negative number). As a measure of spread, the standard bootstrap confidence interval estimation is less affected by skewness.

based on their frequencies of use as raw materials: quartz, tuff, sandstone, chert, and "other." For each category, they reported quantity and weight (Blaser et al., 2002). Unlike Blaser et al. (2002), we were interested in a technological analysis of the raw materials. We decided to separate the raw materials into just two main groups because of the different ways that the materials fracture, as well as the different morphologies of the debitage that result from different fracture patterns.

The two raw material groups in our study are: A, which comprises quartz, quartzite, sandstone, and, very rarely, some other unidentified rocks, and $\mathrm{B}$, consisting of chert and tuff. Quartz pieces comprise the vast majority of group A, while quartzite and sandstone items are rare. We grouped quartz and quartzite together because these kinds of raw material are very hard. Furthermore, these materials break in a similar way, and knapping of these materials often does not produce regular debitage categories. There are a few pieces in the $\mathrm{G}_{3}$ assemblage that are probably sandstone, but we cannot be certain without petrographic analysis. Chunklike pieces were formed sometimes out of quartz and are often a product of human activity, while regular flakes of quartz and quartzite with bulb of percussion, platform, etc., are very rare. Because of their more typical breakage, the second group of raw materials (group B: chert and tuff) are more readily classified into the standard categories (e.g., cortical flakes, noncortical flakes, etc.; see Table 8 and Inizan et al., 1992). Thus, for group A (quartz and related materials) we used the following categories: A1) pebbles and broken pebbles, A2) cortical pebble fragments, A3) flakes and flakelike pieces with cortex, A4) flakes and flakelike pieces without cortex, A5) chunks and chunklike pieces with cortex, A6) chunks and chunklike pieces without cortex, A7) "salami slices," and A8) cores and corelike pieces. We also used a "hammers" category, but since such objects are not debitage, they were not included in the statistics of our analysis.

\section{Group A: quartz and related materials}

Some of the following categories combine both worked and unworked pieces because assessing whether or not individual items in these categories are worked can be difficult. We define a worked piece as a thin flake or blade on which it is possible to recognize dorsal and ventral faces and/or pieces with a butt and bulb of percussion. Non-worked pieces are irregularly shaped pieces on which it is not possible to recognize dorsal and ventral faces and which lack a butt and bulb of percussion.

A1) Pebbles and broken pebbles. This category consists of complete pebbles as well as mostly complete broken pebbles. Broken pebble surfaces are mostly cortex with a minority of non-cortex rock. Items in this category we regard as non-worked. 


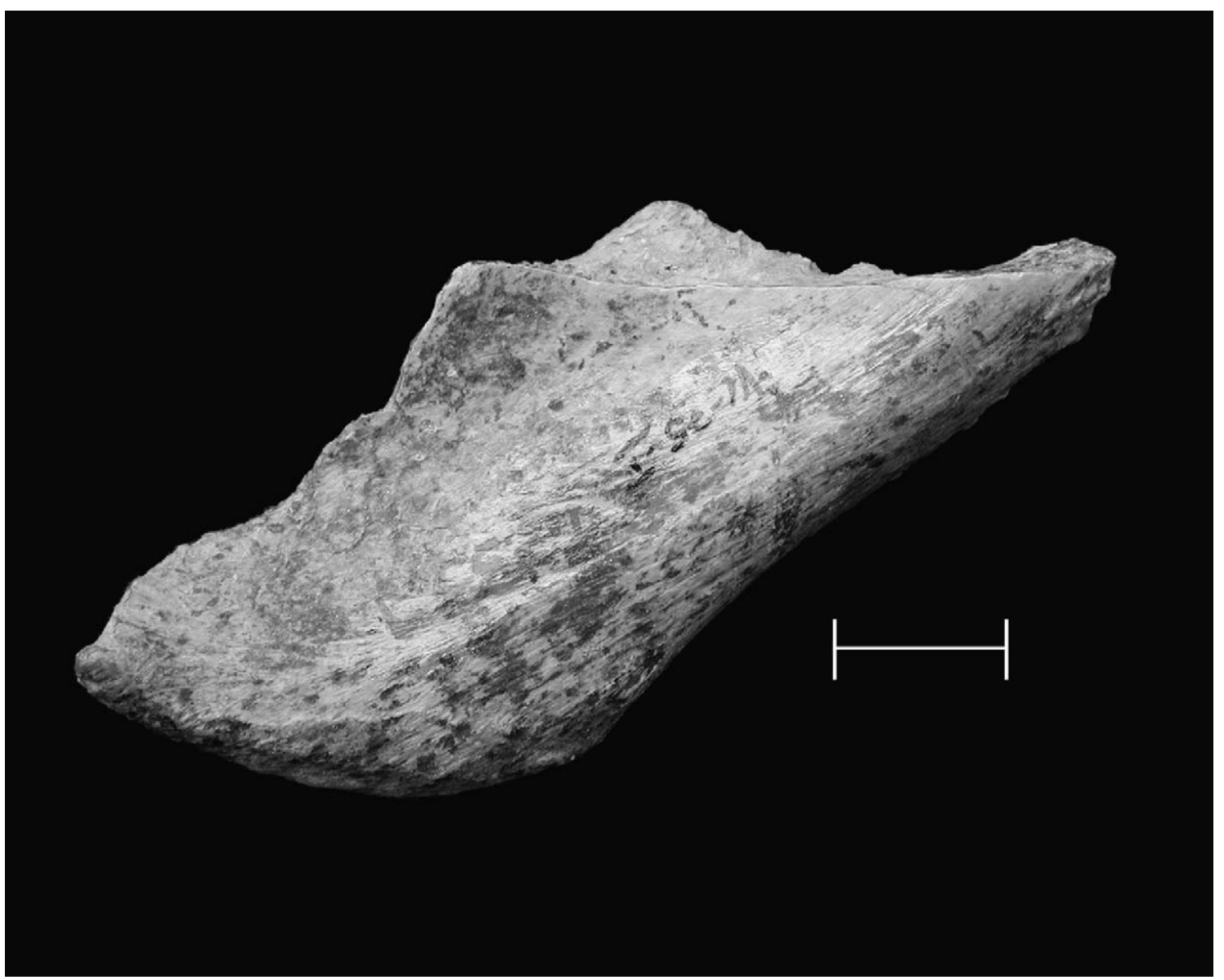

Fig. 18. Dorsal aspect of the scapular fragment, Vi 13.10. Scale is $1 \mathrm{~cm}$.

A2) Cortical pebble fragments. Unlike broken pebbles, $50 \%$ or less of their entire surfaces is cortex. Cortical pebble fragments are also thin relative to broken pebbles, but thick compared to flakes. Sometimes they have a flakelike shape. Most items in this category do not show any working.

A3) Flakes and flakelike pieces with cortex. Flakes with cortex on their dorsal surface have a point and cone of percussion, while the flakelike pieces have a shape like flakes but usually lack a point and cone of percussion and their ventral surface is not always plain. Items in this category usually have cortex on less than $50 \%$ of their dorsal surface. Strict categoriz- ation of the material into flakes and flakelike pieces was not always possible, and therefore we decided to use only one category.

A4) Flakes and flakelike pieces without cortex. These have the same definition as the previous category but lack any cortex except occasionally a cortical platform.

A5) Chunks and chunklike pieces with cortex. Chunk and chunklike pieces are thick fragments with some cortex that lack regular shape. Chunks are regarded as non-worked, while chunklike pieces preserve evidence of working (e.g., striking platform, cone of percussion, etc.). Thus, chunklike pieces are actually thick flakes. 


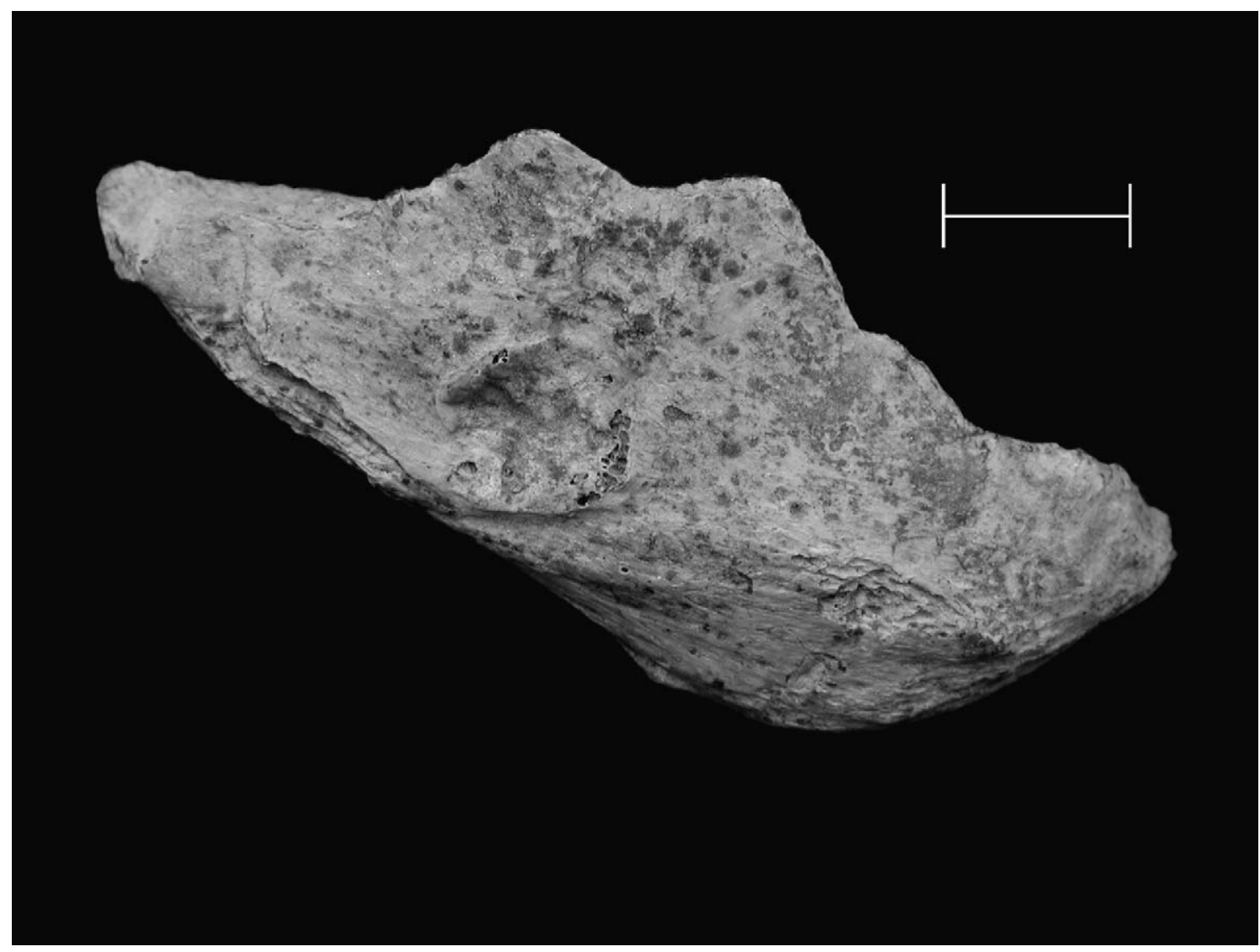

Fig. 19. Ventral aspect of the scapular fragment, Vi 13.10. Scale is $1 \mathrm{~cm}$.

A6) Chunk and chunklike pieces without cortex. Items in this category are defined the same way as those in the previous category, but they lack any cortex on their surfaces.

A7) Salami slices. This name suggests a method of removing transverse slices through a nodule and is usually associated with Quina assemblages in which raw material appears in the form of elongated nodules (Turq, 1989). However, nodules or pebbles can naturally fracture in the form of slices, and this might be the case for items from Vindija assigned to this category.

A8) Cores and corelike pieces. Cores have several flake scars, while corelike pieces have scars that may or may not be flake scars. Morphologically, corelike pieces fall between cores and chunks. Cores are clearly worked, while corelike pieces are also probably worked, but this is less clear.

\section{Group B: chert and tuff}

For classification of chert and tuff lithics, we used standard technological categories (Inizan et al., 1992): B1) Pebbles and broken pebbles, B2) decortification flakes, B3) flakes, B4) blades, B5) chunks with cortex, B6) chunks without cortex and B7) cores (see Table 8).

\section{Interpretation: group A (quartz and related materials)}

Cortical pebble fragments (A2) comprise the largest proportion of the quartz group assemblage 
Table 7

Raw material group A (quartz and related materials) debitage of the $\mathrm{G}_{3}$ Mousterian assemblage

\begin{tabular}{|c|c|c|c|c|c|c|}
\hline & $\begin{array}{l}\text { Unretouched } \\
\text { pieces }(n)\end{array}$ & $\begin{array}{c}\text { Unretouched } \\
\text { pieces }(\%)\end{array}$ & $\begin{array}{c}\text { Retouched } \\
\text { pieces }(n)\end{array}$ & $\begin{array}{c}\text { Retouched } \\
\text { pieces }(\%)\end{array}$ & $\begin{array}{l}\text { All } \\
(n)\end{array}$ & All $(\%)$ \\
\hline A1) Pebbles and broken pebbles & 19 & 7.5 & 0 & 0.0 & 19 & 7.5 \\
\hline A2) Cortical pebble fragments & 60 & 23.6 & 0 & 0.0 & 60 & 23.6 \\
\hline $\begin{array}{l}\text { A3) Flakes and flakelike pieces with } \\
\text { some cortex }\end{array}$ & 32 & 12.6 & 12 & 4.7 & 44 & 17.3 \\
\hline $\begin{array}{l}\text { A4) Flakes and flakelike pieces without } \\
\text { cortex }\end{array}$ & 43 & 16.9 & 9 & 3.6 & 52 & 20.5 \\
\hline $\begin{array}{l}\text { A5) Chunks and chunklike pieces with } \\
\text { cortex }\end{array}$ & 34 & 13.4 & 2 & 0.8 & 36 & 14.2 \\
\hline $\begin{array}{l}\text { A6) Chunks and chunklike pieces } \\
\text { without cortex }\end{array}$ & 32 & 12.6 & 0 & 0.0 & 32 & 12.6 \\
\hline A7) Salami slices & 3 & 1.2 & 0 & 0.0 & 3 & 1.2 \\
\hline A8) Cores and corelike pieces & 8 & 3.1 & 0 & 0.0 & 8 & 3.1 \\
\hline Total & 231 & 90.9 & 23 & 9.1 & 254 & 100 \\
\hline Hammers $^{\mathrm{a}}$ & 4 & & & & & \\
\hline
\end{tabular}

${ }^{a}$ Hammers are excluded since they are not regarded as a source of raw material for knapping. Pebbles, although not utilized, could have been a source of raw material for knapping. Salami slices from Vindija may not be human made, although this term is used for worked debitage.

at $23.6 \%$, while the frequency of flakes and flakelike pieces without cortex (A3) is second highest at $20.5 \%$ (see Table 7). Salami slices (A7) have the lowest frequency at $1.2 \%$. The majority of the cortical pebble fragments (A2) do not show any signs of human modification, while the majority of categories A3 (flakes and flakelike pieces with some cortex), A5 (chunks and chunklike pieces with cortex), and A6 (chunks and chunklike pieces without cortex) possibly show or definitely show signs of human modification. It is possible that the majority of items in category A2 (cortical pebble fragments) are not artifacts but are instead the result of geological processes, such as cryoturbation. On the other hand, many of the pieces in categories A5 (chunks and chunklike pieces with cortex) and A6 (chunks and chunklike pieces without cortex) are not the result of natural activity and were produced by humans (i.e., they exhibit a point of percussion, a platform, and/or a ventral surface with a bulb of percussion or a plain ventral surface, which may indicate working). The chunk form of these pieces was caused by the breaking pattern of the quartz and quartzite, and this is the reason why they are not classified as regular flakes but as thick pieces. Thus it is very hard to put all of the categories into a reduction sequence, but we can assume that the items in category A3 (flakes and flakelike pieces with some cortex) and some in A5 (chunks and chunklike pieces without cortex) are followed by the items in categories A4 (flakes and flakelike pieces without cortex) and some in A6 (chunks and chunklike pieces without cortex) in the chronology of production. Some objects in categories A3, A4, and A5 were transformed into tools (Fig. 20). The percentage of retouched pieces in the quartz and quartzlike (group A) $\mathrm{G}_{3}$ assemblage is relatively low, at $9.1 \%$.

\section{Interpretation: group B (chert and tuff)}

Flakes are the most numerous debitage items in the chert and tuff group (56.2\%), followed by decortification flakes at $14.6 \%$ (Table 8). Only one piece is included in the pebbles and broken pebbles category, which contrasts with the quartz and related materials group (A). All categories, except some chunks with and without cortex, were subjected of human modification. The majority of decortification flakes and the minority of regular flakes were transformed into tools (Table 8, 


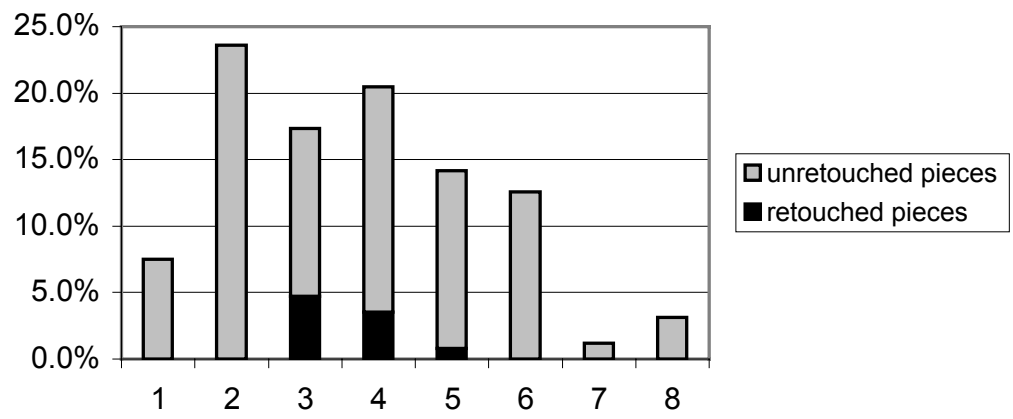

Fig. 20. Frequency bar chart of debitage made mainly on quartz: (1) pebbles and broken pebbles, (2) cortical pebble fragments, (3) flakes and flakelike pieces with some cortex, (4) flakes and flakelike pieces without cortex, (5) chunks and chunklike pieces with cortex, (6) chunks and chunklike pieces without cortex, (7) salami slices, and (8) cores and corelike pieces.

Table 8

Raw material group B (chert and tuff) debitage of the $G_{3}$ Mousterian assemblage

\begin{tabular}{|c|c|c|c|c|c|c|}
\hline & $\begin{array}{l}\text { Unretouched pieces } \\
\qquad(n)\end{array}$ & $\begin{array}{c}\text { Unretouched pieces } \\
(\%)\end{array}$ & $\begin{array}{c}\text { Retouched pieces } \\
(n)\end{array}$ & $\begin{array}{c}\text { Retouched pieces } \\
(\%)\end{array}$ & All $(n)$ & $\begin{array}{l}\text { All } \\
(\%)\end{array}$ \\
\hline $\begin{array}{l}\text { B1) Pebbles and broken } \\
\text { pebbles }\end{array}$ & 0 & 0.0 & 1 & 1.0 & 1 & 1.0 \\
\hline B2) Decortification flakes & 4 & 4.2 & 10 & 10.4 & 14 & 14.6 \\
\hline B3) Flakes & 34 & 35.4 & 20 & 20.8 & 54 & 56.2 \\
\hline B4) Blades & 1 & 1.0 & 4 & 4.2 & 5 & 5.2 \\
\hline B5) Chunks with cortex & 2 & 2.1 & 0 & 0.0 & 2 & 2.1 \\
\hline B6) Chunks without cortex & 11 & 11.5 & 2 & 2.1 & 13 & 13.6 \\
\hline B7) Cores & 7 & 7.3 & 0 & 0.0 & 3 & 7.3 \\
\hline Total & 59 & 61.5 & 37 & 38.5 & 96 & 100 \\
\hline Hammers $^{\mathrm{a}}$ & 1 & & & & & \\
\hline
\end{tabular}

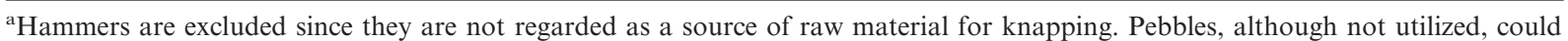
have been a source of raw material for knapping.

Fig. 21). Five blades, four of which were retouched, are found in level $\mathrm{G}_{3}$.

Use of several types of raw material with different fracturing characteristics for knapping in level $\mathrm{G}_{3}$ resulted in differing debitage morphologies. Quartz dominates while quartzite and sandstone are rare in group A (quartz and related materials). For many pieces in raw material group A, it was not possible to establish with certainty whether or not they were subjected to human modification or natural agencies. On the other hand, the chert and tuff group (B) consists of typical debitage categories where only some chunks might not have been the products of hu- man manufacture. There are five blades produced on local raw materials, which suggests the presence of blade technology at the site. However, as a blade core was not found, it is also possible that these pieces were brought to the site from another location. Levallois technology is not present in level $\mathrm{G}_{3}$. The percentage of retouched pieces in the chert and tuff assemblage is high, about 39\%, relative to unretouched debitage (see Table 8, Fig. 23 ). This might suggest that some of the tools were made outside the cave or that they have been brought from other sites. However, they were all made on local raw materials (Kurtanjek and Marci, 1990). 


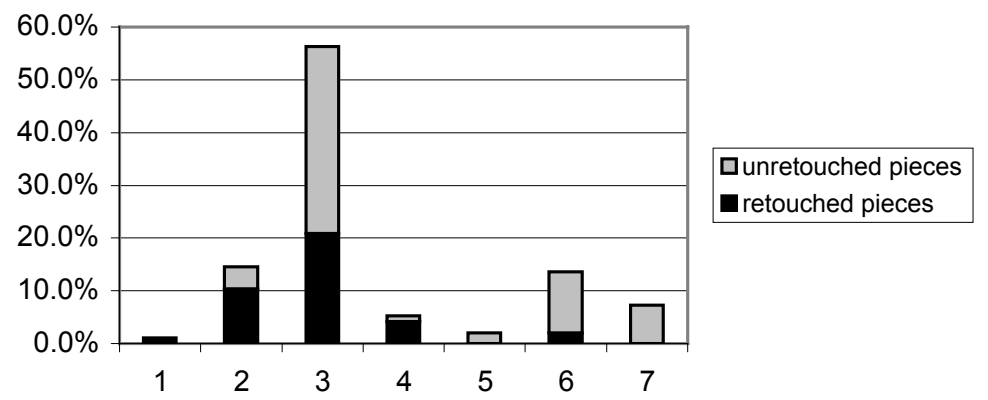

Fig. 21. Frequency bar chart of debitage made on chert and tuff: (1) pebbles and broken pebbles, (2) decortification flakes, (3) flakes, (4) blades, (5) chunks with cortex, (6) chunks without cortex, and (7) cores.

Table 9

Main tool type categories of the $\mathrm{G}_{3}$ Mousterian

\begin{tabular}{lcccr}
\hline & $\begin{array}{c}\text { Chert and } \\
\text { tuff }(\mathrm{n})\end{array}$ & $\begin{array}{c}\text { Quartz } \\
(\mathrm{n})\end{array}$ & $\begin{array}{c}\text { Total } \\
(\mathrm{n})\end{array}$ & $\%$ \\
\hline 1) Sidescrapers & 8 & 6 & 14 & 23.3 \\
2) Notches and & 10 & 7 & 17 & 28.3 \\
denticulates & & & & \\
3) Retouched flakes & 10 & 9 & 19 & 31.7 \\
4) Endscrapers & 4 & 0 & 4 & 6.7 \\
5) Other & 5 & 1 & 6 & 10.0 \\
\hline Total & $\mathbf{3 7}$ & $\mathbf{2 3}$ & $\mathbf{6 0}$ & $\mathbf{1 0 0 . 0}$ \\
\hline
\end{tabular}

Among the tools, the most frequent items for both raw material categories combined are retouched pieces at $31.7 \%$ (Table 9). Some of the retouched pieces are blades (Fig. 22, nos. 5 and 6). The second largest category includes notches (Fig. 22, no. 8) and denticulated pieces (Fig. 22, no. 7) at $28.3 \%$ and is followed by sidescrapers $(23.3 \%)$. Various types of sidescrapers are present in level $\mathrm{G}_{3}$ (see Fig. 22, nos. 9-12). Some of them were made of quartz (Fig. 23). Tools from all of the mentioned categories are mostly made on chert and tuff (Fig. 23), as are all of the endscrapers. This category is represented by three endscrapers on flakes (Fig. 22, nos. 1, 2, and 4) and an endscraper on a broken blade (Fig. 22, no. 3). They are smaller and less crudely made than is common in the Mousterian.

\section{Newly identified tools}

During our analysis, we newly identified ten tools in the $\mathrm{G}_{3}$ lithic assemblage. For the most part, they are simply and partially retouched pieces. Frequencies of notches and denticulated pieces and sidescrapers are smaller then previously reported by Karavanić and Smith (1998). This is because we have attributed some of the less typical finds from these categories to retouched pieces. Also, five previously unpublished tools are shown in Fig. 24. These tools, all made on quartz or quartzite, are: 1) a denticulated piece, 2) a simple straight sidescraper, 3) a notched piece, 4) a transverse convex sidescraper, and 5) a retouched piece. Although these five tools are diagnostic for cultural determination, they do not affect the previous determination of the $\mathrm{G}_{3}$ industry as late Mousterian. This designation is based on the high frequencies of sidescrapers, notches, and denticulates in the $G_{3}$ assemblage (Karavanić and Smith, 1998).

\section{Comparison of $G_{3}$ to Middle and Upper \\ Paleolithic raw material use}

Raw material use differs between level $\mathrm{G}_{3}$ and earlier Middle Paleolithic levels at Vindija. Fewer quartz and nearly double the percentage of chert artifacts were left by the $\mathrm{G}_{3}$ hominids compared to the earlier Middle Paleolithic (Table 10). The differences between the $\mathrm{G}_{3}$ and earlier Middle Paleolithic raw material use foreshadow the pattern of raw material use in the Upper Paleolithic levels at the site. However, the change in raw material use from $\mathrm{G}_{3}$ to the Upper Paleolithic is far more drastic than that seen from the earlier Middle Paleolithic to level $G_{3}$ (Table 10). Level $G_{1}$, which combines Middle and Upper Paleolithic 

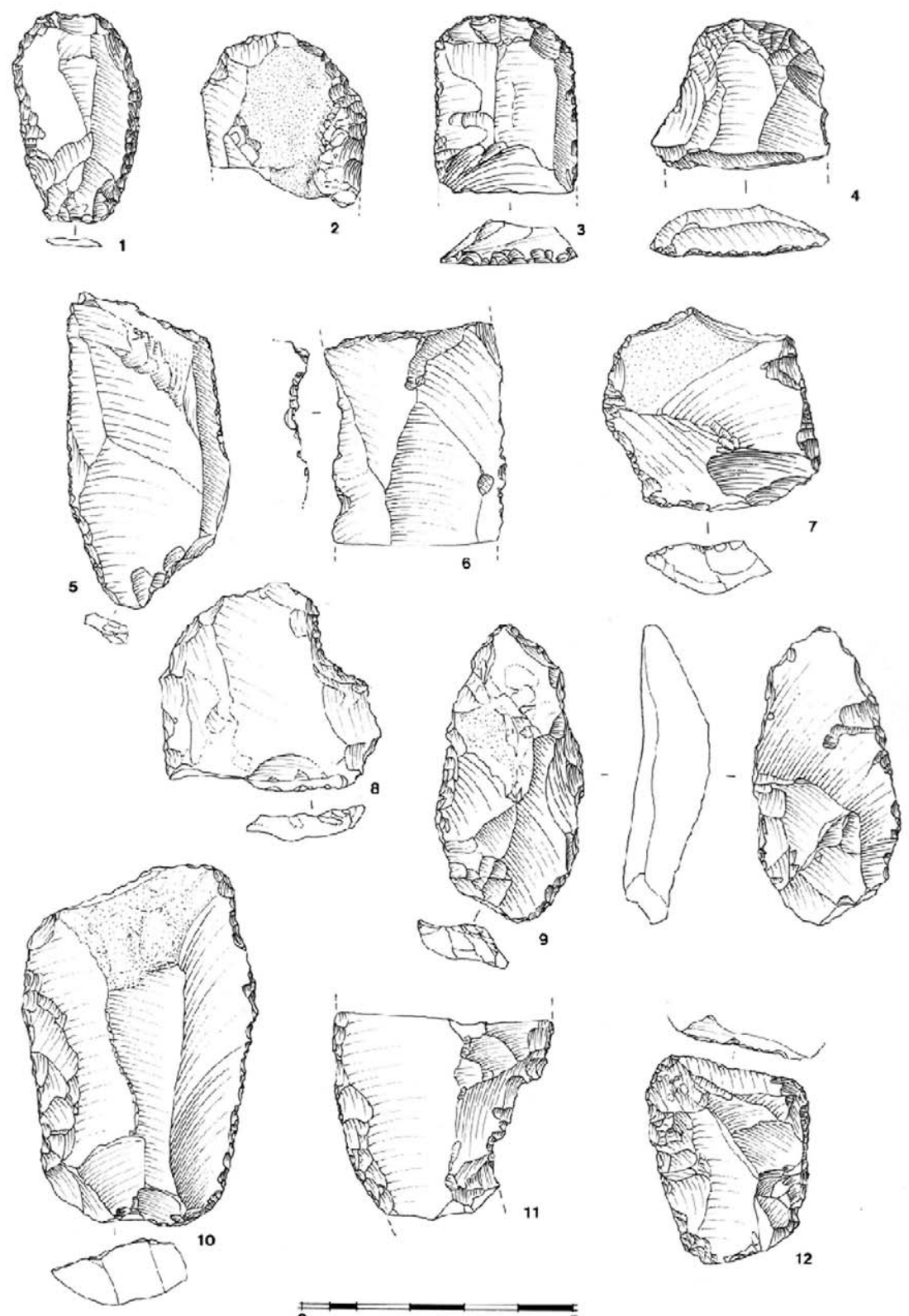

Fig. 22. Tools from Vindija level G3: (1-4) endscrapers, (5-6) retouched pieces, (7) denticulated piece, (8) notched piece, (9) convergent sidescraper with bifacial retouch, (10) double straight convex sidescraper, (11) single convex sidescraper, (12) alternate retouched sidescraper (drawing by M. Bezic). 


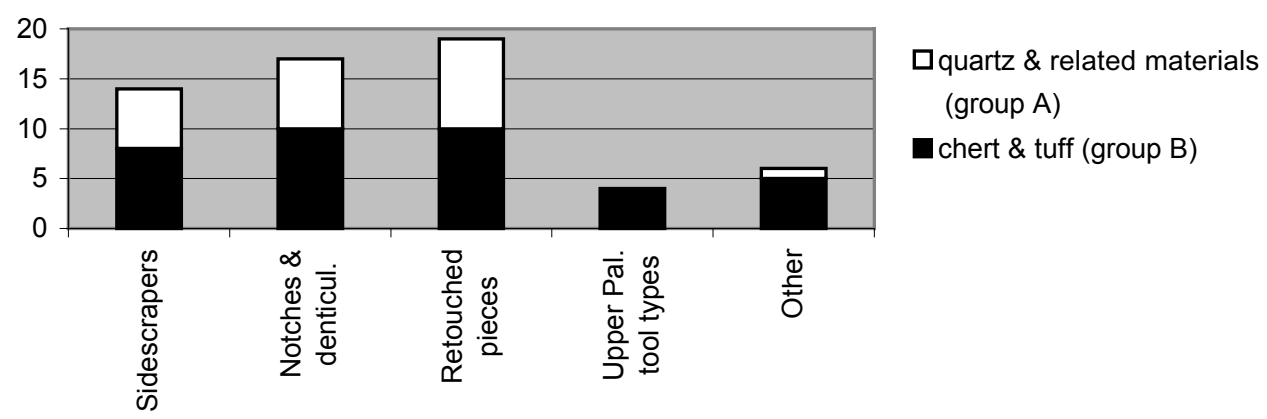

Fig. 23. Quantity bar chart of main tool types from level $\mathrm{G}_{3}$.
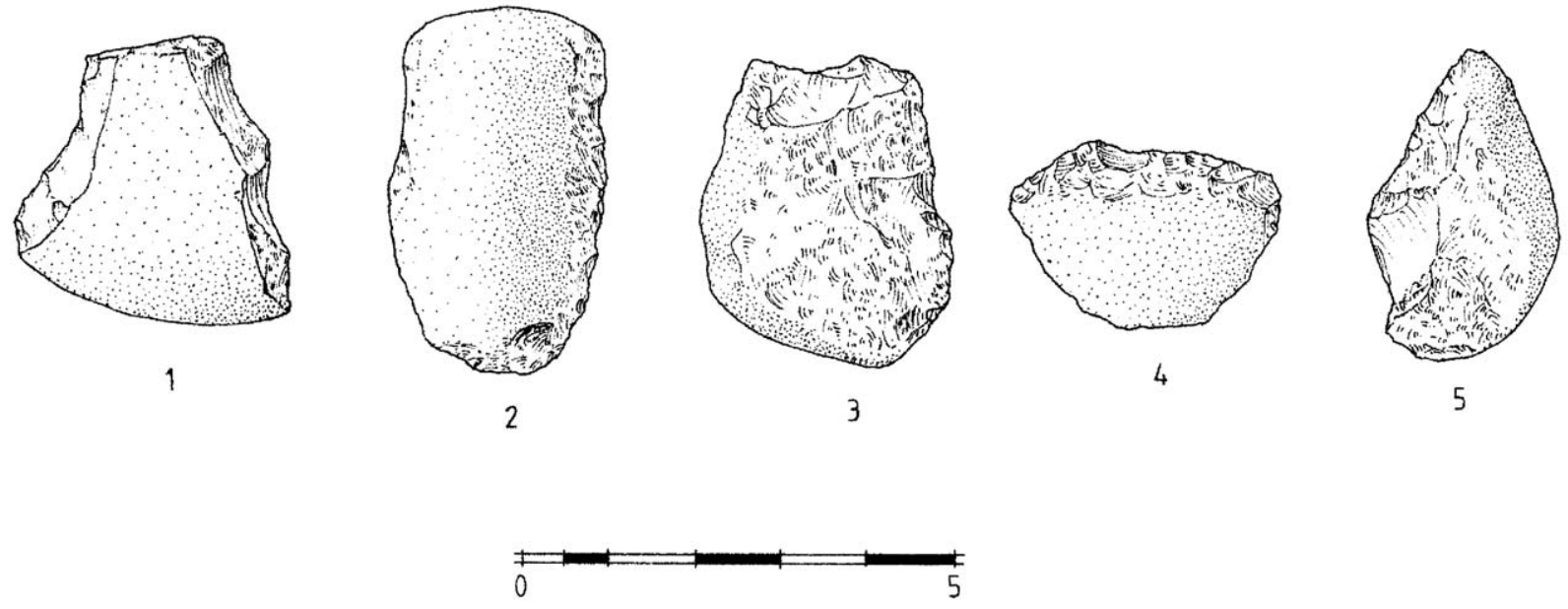

Fig. 24. Five previously unpublished quartz/quartzite tools from Vindija level $G_{3}$ : (1) denticulate piece, (2) simple straight sidescraper, (3) notched piece, (4) transverse convex sidescraper, (5) retouched piece (drawing by M. Bezic).

elements in its artifact assemblage, has a pattern of raw material use that is intermediate between level $\mathrm{G}_{3}$ and the Upper Paleolithic (Table 10).

\section{Bone retouchers from the Vindija Middle Paleolithic?}

The use of bone tools during the Lower and Middle Paleolithic has been discussed in the literature since the beginning of the 20th century. Some bone fragments with marks on their surface have been interpreted as flaking tools (retouchers) and these objects have been presented in both older and more recent publications (e.g., Martin, 1906; Bordes, 1961; Leonardi, 1979; Vincent, 1988;
Nami and Scheinsohn, 1997; Bartolomei et al., 1994).

The marks on retouchers can sometimes be clearly differentiated from other generic marks on bone that are caused by breakage, defleshing, jointing, or skinning, as well as from the marks of gnawing or trampling and other activities (see Binford, 1981; Bonnichsen et al., 1989; Blumenschine et al., 1996; Villa and Bartram, 1996). Generally, we can define retouchers as bone objects with small and punctiform pits or parallel linear marks on the distal end, vertical on the main axes of the object. In some cases, the marks caused by non-human agents of bone modification are similar to those caused by retouching, which can 
Table 10

Distribution of raw materials ${ }^{\mathrm{a}}$

\begin{tabular}{lcccc}
\hline Raw material & MP levels (excluding $\left.\mathrm{G}_{3}\right)$ & Level $\mathrm{G}_{3}$ & Level $\mathrm{G}_{1}$ & \multicolumn{2}{c}{ UP levels (excluding $\left.\mathrm{G}_{1}\right)$} \\
& $(\%)$ & $(\%)$ & $(\%)$ & 29 \\
\hline Quartz and related materials & 79.0 & 72.6 & 49.1 & 64 \\
Chert and tuff & 21.0 & 27.4 & 50.9 & 100.0 \\
Total & 100.0 & 100.0 & 100.0 & \\
\hline
\end{tabular}

${ }^{a}$ After Kurtanjek and Marci (1990) and Blaser et al. (2002).

make the determination of the retouchers more difficult.

T. D. White identified nine possible bone retouchers among the faunal remains from the Paleolithic levels of Vindija. One of these is from the Upper Paleolithic level $\mathrm{F}_{\mathrm{d}}$, another is from either $F_{d}$ or Unit $G$, two are from level $G_{3}$, one is from $G_{d}$ (lower part of unit $G$, probably level $G_{4}$ or $G_{5}$ ), and four from the general provenience of unit G. Two pieces will be discussed here. One of these is a deer metatarsal fragment (D. Brajković, personal communication) from the late Mousterian level $\mathrm{G}_{3}$ (Fig. 25, no. 2), while the other is a long bone fragment of a large animal from the lower levels of $\mathrm{G}\left(\mathrm{G}_{4}\right.$ or $\left.\mathrm{G}_{5}\right)$ (Fig. 25, no. 3). Although the latter find is stratigraphically older than level $\mathrm{G}_{3}$, we include it in the analysis because it bears different marks than the $\mathrm{G}_{3}$ find, which, through comparison with experimental material, can help to reconstruct the way in which these possible retouchers were used (percussion or pressure).

One of us (I.K.) and Tomislav Šokec conducted a preliminary experiment to help determine what sort of marks would be made on bone retouchers when used for percussion and pressure flaking (Karavanić and Šokec, in press). A fresh radius of a domesticated cattle was broken with a chopping tool and used for the experiment. The experimental bone retoucher was used to work chert. Instead of the ends of the bone, the middle parts of the bone were used since this is where such possible retouch marks were present on the potential retouchers from Vindija. Retouch obtained by percussion on chert flakes is stepped, steep or semisteep, and, in some places, slightly denticulate, while retouch obtained by pressure is diminutive, shallow, semi-steep, and slightly stepped. Sharp flake edges were usually chosen to perform pressure retouching during the experiment. Therefore, angles between the dorsal and ventral surfaces of the experimentally pressure-retouched flakes were usually between 50 and 55 degrees, while the same angles on the flakes retouched by soft hammer percussion technique usually varied between 60 and 85 degrees. A few tools from the late Mousterian levels of Vindija $\left(\mathrm{G}_{3}, \mathrm{G}_{2 / 3}, \mathrm{G}_{2}, \mathrm{G}_{/ \mathrm{g}}\right)$ exhibit angles less than 55 degrees between dorsal and ventral surfaces of the working edge, and they might have been retouched by pressure.

Two types of marks, one due to percussion and the other due to pressure flaking, were observed in the experiment. The marks made with percussion were punctiform pits with distinctive scaling on the edges (Fig. 25, no. 1a-left end of the bone; Fig. 25 , no. 1), while the marks made with pressure were short linear channels with a U-shaped crosssection (Fig. 25, no. 1b-right part of the bone; Fig. 26, no. 3). According to Nami and Scheinsohn (1997), pitting can sometimes be caused by pressure retouching when pointed retouchers are used, which was not the case in our experiment, where pitting was exclusively associated with the percussion technique. Punctiform pits were also present on the Vindija fragment from lower unit G (Fig. 25, no. 3-left part of the bone; Fig. 26, no. 2), while short linear channels are on the piece from level $\mathrm{G}_{3}$ (Fig. 25, no. 2-right part of the bone; Fig. 26, no. 4). However, there are some morphological differences between marks on the experimental and archaeological objects. The majority of pits on the archaeological material, are more lenticular than the pits on the experimental material which are often triangular. The position 

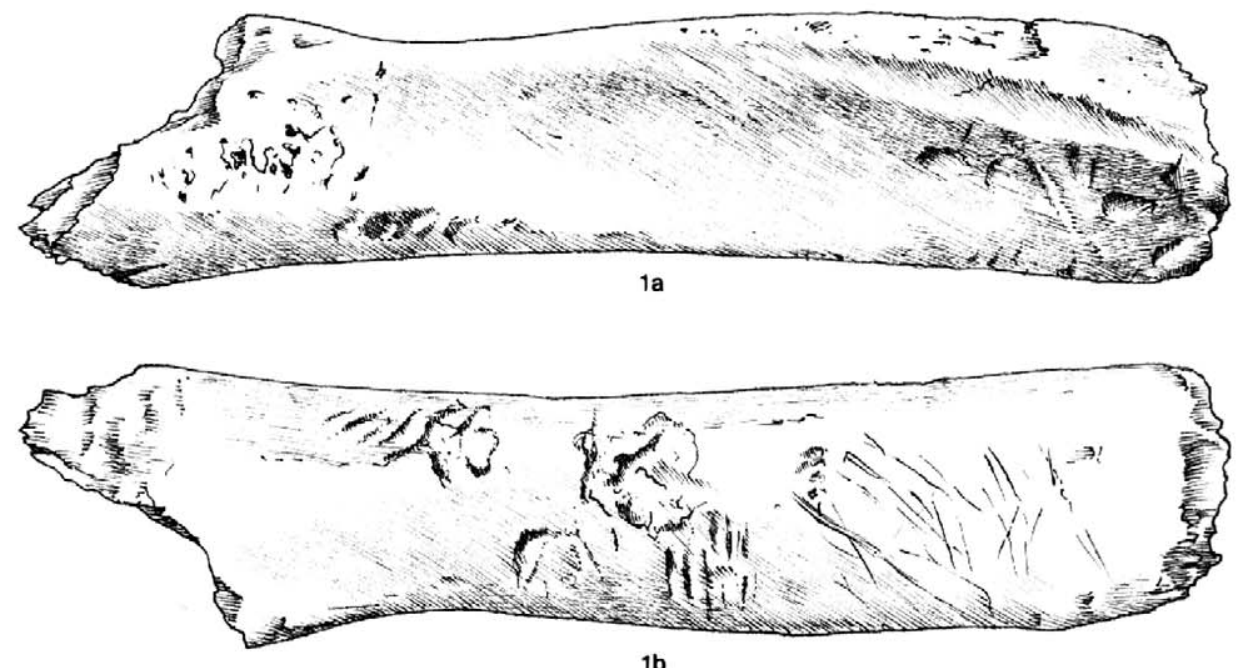

$1 b$
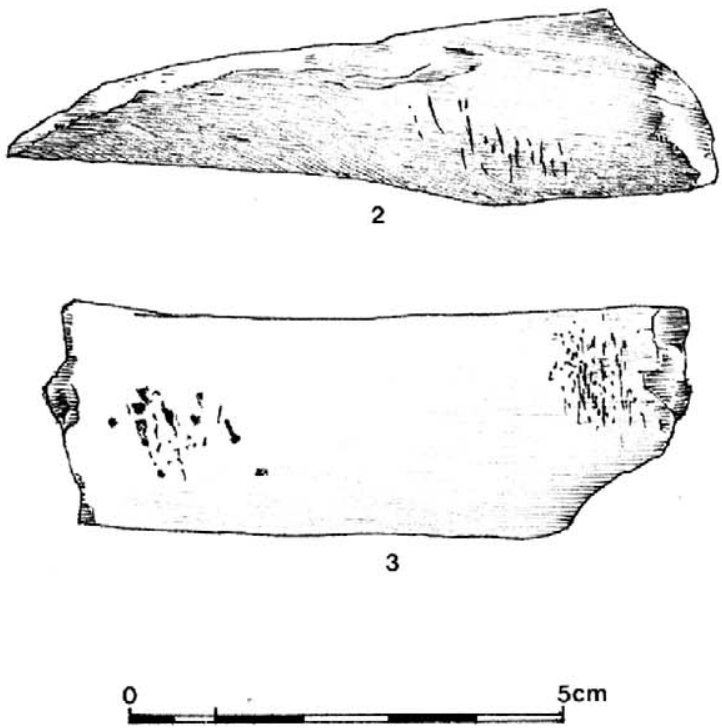

Fig. 25. Retouchers: (1a) experimental percussion flaking marks on an ulna (left), (1b) experimental pressure flaking marks on an ulna (right); (2) probable pressure flaking marks on bone fragment from Vindija level $\mathrm{G}_{3}$; (3) percussion flaking marks (left) and probable pressure flaking marks (right) on bone fragment from Vindija unit $\mathrm{G}_{\mathrm{d}}$ (drawing by $\mathrm{M}$. Gregl).

of marks on possible retoucher from Vindija $\mathrm{G}_{3}$ is vertical or at a slight angle in relation to the long axis of the artifact, while the position on the experimental retoucher varies to a greater extent. The reason for this may lie in the lesser skill of the experimenter and the slipperiness of the bone that 


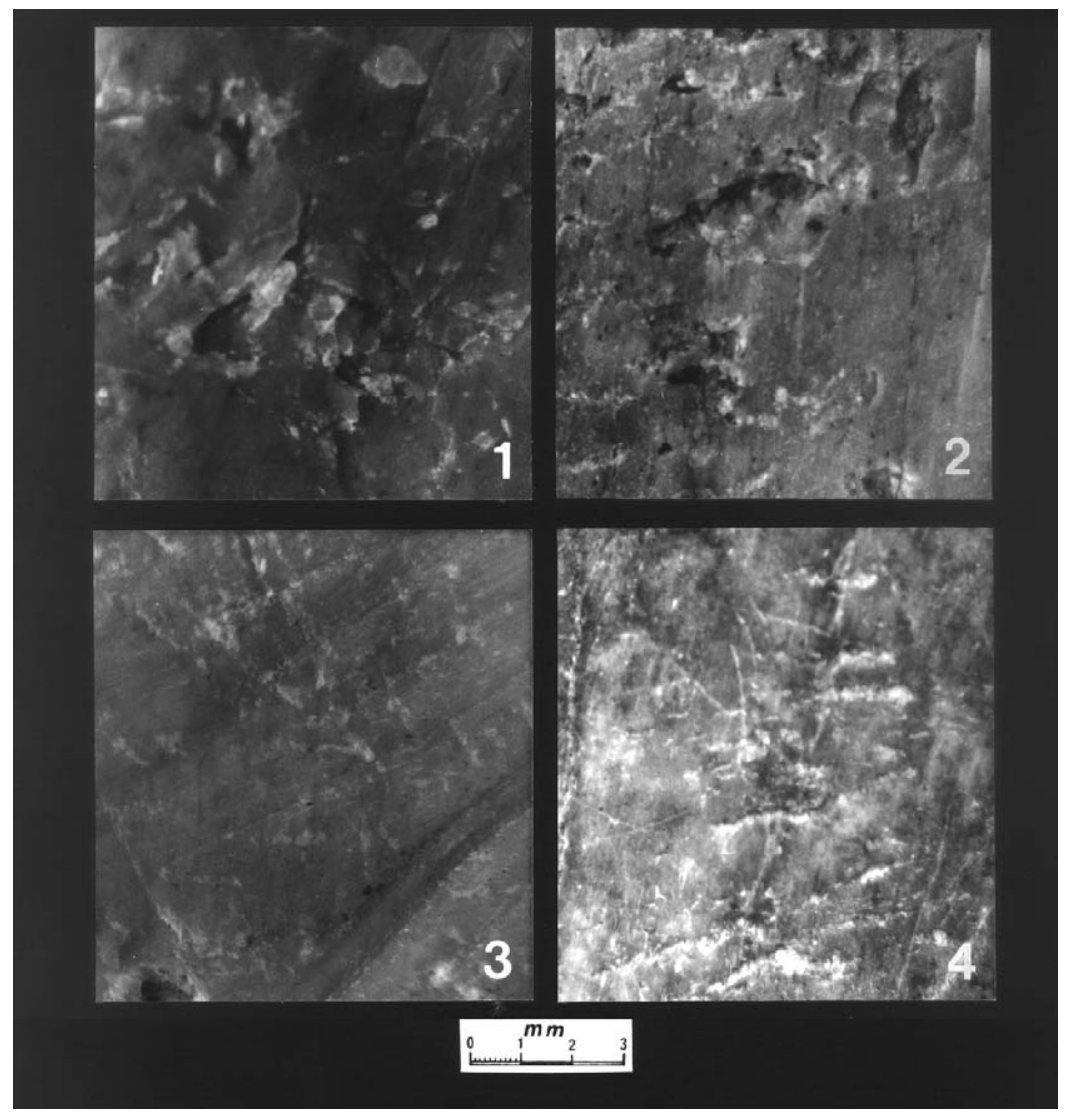

Fig. 26. Microscopic view of: (1) experimental percussion flaking marks on an ulna; (2) percussion flaking marks from Vindija unit $\mathrm{G}_{\mathrm{d}}$; (3) experimental pressure flaking marks on an ulna; (4) probable pressure flaking marks from Vindija level G.

was used. Furthermore, parallel linear marks on experimental pressure retouchers are longer and deeper than these on the archaeological fragment. Deeper marks on experimental material than those on the archaeological material probably resulted from larger force applied to these objects, while the slipperiness of the bones, from which it was not possible to completely remove periosteum before use, caused their long length due to sliding of the bone along the edge of the retouched artifact. However, it is possible that some differences depend on the elasticity and hardness of the used bone (Vincent, 1988), which probably vary depending on the age of the animal, the skeletal element, and the time that had passed since the death of the animal. The marks on experimental pressure material are more frequent than the marks on archaeological material, which can be explained by different intensity of tool use (use of the experimental tool was more extensive).

Another important issue concerns retoucher size. Small retouchers probably are not always the result of breakage during use or a consequence of overburden weight. Besides the archaeological material, the small, but efficient experimental soft hammer made of the piece of ulna shows that even the small percussion retouchers could still have been functional.

The preliminary experiment established that the marks on the possible Vindija retouchers were very similar to those produced experimentally. Furthermore, some lithic tools from Vindija show parallel or sub-parallel retouch on a sharp angle, which suggests the possible use of pressure retouching. 
The experiment has also shown that pressure retouching, using the middle part near the distal edge of bone retouchers (not the tip), can produce different kinds of retouch but not necessarily parallel retouch, which has been often exclusively used as proof for the presence of the pressure retouching technique.

\section{Discussion}

Vindija Cave has played an important role in our understanding of Neandertals, the origin of modern humans in Europe, and the European Middle/Upper Paleolithic transition. Many aspects of the Vindija unit G hominid fossil and archaeological remains have been described as modernlike in relation to other Neandertals, especially when compared to the discoveries from the nearby site of Krapina (e.g., Wolpoff et al., 1981; Malez and Ullrich, 1982; Smith, 1984, Frayer et al., 1993). Furthermore, the hominid fossils from level $\mathrm{G}_{1}$ are the youngest Neandertals known (Smith et al., 1999). The probable association of Upper Paleolithic implements, including bone tools that are typologically Aurignacian, with the $\mathrm{G}_{1}$ Neandertals is also significant (Wolpoff et al., 1981; Smith and Ahern, 1994; Karavanić, 1995; Miracle, 1998; Karavanić and Smith, 1998, 2000; Straus, 1999). Although the bone tools from level $\mathrm{G}_{1}$ aretypologically Aurignacian, they also appear in nonAurignacian contexts in central Europe (Miracle, 1998).

The ten newly identified retouched lithics from level $\mathrm{G}_{3}$ and the seven new hominid specimens, although fragmentary, add to our understanding of the Vindija hominids. Only six postcranial specimens from Vindija have been previously described. Of the three postcranial specimens newly described here, Vi 13.8 (proximal radial shaft) and 13.10 (scapular fragment) exhibit diagnostic features that allow us to tentatively designate them as Neandertals. Vi 13.7, a portion of ilium, also likely represents a Neandertal given its $G_{3}$ provenience, although it lacks diagnostic anatomy. All of the postcranial fossils preserve anatomy not previously found in the Vindija hominid sample.
Two of the new fossils, Vi 11.52 (mandibular ramus fragment) and 13.10 (scapular fragment), are the first recovered from stratigraphic unit I. Both of these fossils exhibit diagnostic Neandertal anatomy and provide the first evidence of hominid fossil remains in this early unit in the Vindija sequence. Vi 11.52 has a medial pterygoid tubercle and is similar in form to $\mathrm{Vi} 226, \mathrm{a} \mathrm{G}_{3}$ Neandertal specimen. Vi 13.10 possesses the inferior portion of a dorsally located sulcus on the axillary border. This form of the axillary border is found in its highest frequency among Neandertals and is present on the other scapular specimen (Vi 209) from Vindija (Wolpoff et al., 1981). Although Wild et al. (2001) report a radiocarbon date for unit I of $37,000 \pm 600 \mathrm{yrs} \mathrm{BP}$, this is likely an underestimate of its actual age. Unit I consists of a paleosoil, which is most likely the result of a warm or mild climate (Wolpoff et al., 1981), and it is clearly older than level $G_{3}$ based on stratigraphy. Since unit $G_{3}$ has been correlated to the Lower Würm stadial and unit $\mathrm{K}$ represents Riss-Würm interglacial (Wolpoff et al., 1981), unit I might be from the Brörup interstadial following the Moravian karst sequence (Musil and Valoch, 1966; Valoch, 1968). Further work will be required to better understand the chronological position of unit I.

\section{The unit G hominids and Late Pleistocene biocultural change}

Although Paleolithic artifacts come from most units at Vindija, hominid fossils are limited to but a few levels. Unit $G$ has yielded the largest sample of hominid fossils from the site. Thus, in terms of an integrated biocultural perspective, unit $G$ can provide us the most information about the Vindija hominids. Both biologically and culturally, the unit $\mathrm{G}$ hominids were different from earlier Middle Paleolithic hominids in the area and were, in many ways, more similar to post-Neandertal Upper Paleolithic humans than were earlier Neandertals. Although once thought to represent evidence to clear regional continuity in south-central Europe (e.g., Smith and Ranyard, 1980; Wolpoff et al., 1981; Smith, 1984), the Vindija unit G evidence now points to a much more complex pattern of biocultural change in this region associated with 
the Neandertal/Modern and Middle/Upper Paleolithic transitions (e.g., Smith, 1994; Karavanić and Smith, 1998).

\section{Anatomical change}

Smith, Wolpoff, and others (Smith and Ranyard, 1980; Wolpoff et al., 1981; Smith, 1984; Frayer et al., 1993; Wolpoff, 1999) have posited that the unit $\mathrm{G}$ hominids were transitional between earlier Neandertals and Upper Paleolithic modern humans. Aspects of the unit $\mathrm{G}$ hominids that are intermediate include: reduced midfacial prognathism, reduced nasal breadth, thinner cranial vaults, development of incipient chins, reduction and shape changes of the supraorbital torus in a manner that converges on early modern Upper Paleolithic humans, and a scapular glenoid fossa breadth that falls within the modern range (Wolpoff et al., 1981; Smith, 1984; Smith and Trinkaus, 1991; Ahern et al., 2002). The anatomy of the newly associated cranial vault, Vi 284-230255-256, and the newly identified fossils adds support to the transitional interpretation of the Vindija hominid sample. Compared to most Neandertals, Vi 284-230-255-256 has 1) less postorbital constriction, 2) less projecting and thinner supraorbital tori, 3) a braincase that is broad relative to the upper face, 4 ) a higher vault with a rounded forehead (although see Spy 2), and 5) a less rugose temporal line and fossa. Despite these modernlike features, Vi 284-230-255-256, like the Vindija $G$ sample as a whole, exhibits many archaic/Neandertal features that prevent its classification as early modern human. Unlike early modern Europeans (even robust individuals like Předmosti 3 and Mladeč 5), Vi 284-230-255-256 lacks a supraorbital trigon and the coinciding straight/flat lateral supraorbital segment; has a less vertical anterior frontal squama; has a large frontomalar suture which likely corresponds to a large and columnar lateral orbital pillar; and exhibits a laterally extensive frontal sinus that does not extend into the frontal squama. Although Vi 284-230-255-256 is more modernlike than the second most complete Vindija specimen, Vi 261-275-278, its supraorbital size and shape is not exceptional for the Vindija sample as a whole.
The newly identified cranial specimens are fragmentary but provide a few new details about the Vindija hominid sample. Two of the four cranial fossils derive from unit $\mathrm{G}$, another, Vi 11.52 (discussed above), comes from unit I, while Vi 11.48 lacks provenience. Compared to Krapina specimens, Vi 11.47 and 11.49 are gracile. Although individual, sex-related, and ontogenetic variation are possible explanations for this difference, temporal change cannot be eliminated as an explanation. The frontal squama fragment Vi 11.48 is thin compared to Vi 256, Vi 278, and the Krapina specimens. However, since this fossil lacks provenience, its anatomy is not clearly relevant to an understanding of the unit $\mathrm{G}$ hominids.

Some paleoanthropologists (Howell, 1984; Stringer et al., 1984; Bräuer, 1989, 1992; Klein, 1999; Stringer and Gamble, 1993) have suggested that the transitional appearance of the unit $G$ hominid sample may be the result of sample bias and/or small body size. Age and/or sex sample composition bias is unlikely, at least for the supraorbital sample (Ahern, 1998; Ahern et al., 2002), and Trinkaus and Smith (1995) contend that body size of the Vindija hominids was not significantly smaller than other Neandertals. Trinkaus and Smith (1995) compared dimensions of postcranial specimens Vi 209, Vi 300, and Vi 203 with other Neandertals. The articular height of Vi 209's scapular glenoid lies close to the middle of the Neandertal range. The articular length of the Vi 300 proximal hand phalanx falls slightly below the Neandertal mean, and the basal articular diameter of the proximal fifth metatarsal Vi 203 is small relative to the Krapina Neandertals but not to other Neandertals. The new postcranial specimens, described here, lack all but a few replicable measurements that can be used for size comparison. The distance from the posterosuperior-most point of the acetabular notch to the maximum height of the greater sciatic notch on Vi 13.7 is small compared to Feldhofer 1 and EuroAmericans, but is only $2 \mathrm{~mm}$ less than in Krapina 207. However, this measurement may be more of a function of acetabular notch form than overall body size. The partial radius Vi 13.8 (from $\mathrm{G}_{1}$ ) appears small, but its midshaft circumference falls within 1 standard deviation of the Neandertal 
mean. The inferior angle of the scapula Vi 13.10, although not from unit $G$, is robust and may represent a larger than average individual. Thus, evidence from the new postcranial specimens does not challenge Trinkaus and Smith's (1995) contention that Vindija Neandertal body size was not unusually small.

\section{Behavioral change}

Tools in the Mousterian levels of Vindija were probably retouched by both hard and soft hammers. We can presume that quartz and similar materials were retouched by hard hammers, while hard and soft hammers may have been used for retouching chert and tuff. Furthermore, two different kinds of marks on the possible bone retouchers from Mousterian levels at Vindija suggest that both percussion and pressure techniques were used in the final stage of tool production. However, the use of retouch by the unit $G$ hominids might not be indicative of any technological difference from earlier or contemporary Middle Paleolithic peoples. In Croatia, Middle Paleolithic retouchers have also been reported from Krapina (PatouMathis, 1997) and Veternica Cave near Zagreb (Malez, 1981). In the case of Veternica, Malez (1981) suggested percussion retouching, or the use of fragments as supports (or anvils) on which retouching was done. Thus, rather than being a unique feature of the Vindija late Mousterian hominids, Neandertals, in general, were apparently capable of both percussion and pressure retouching using bone retouchers. This ability has been questioned by Bordes (1961), but more recently supported by Shchelinskiï (Plisson, 1988) on the basis of a comparison of archaeological and experimental material. Further analysis, especially of taphonomic processes, is required before we can definitively determine whether or not the Vindija bones were used as both percussion and pressure retouchers.

Like the $\mathrm{G}_{3}$ hominid sample, which exhibits more modernlike anatomy than earlier Neandertals, the $\mathrm{G}_{3}$ lithic assemblage has more Upper Paleolithic features than do earlier Middle Paleolithic assemblages from the site. Although flake technology dominates in the $G_{3}$ late Mousterian assemblage, there is also evidence of blade and bifacial (retouch) technology, while the Levallois method was not used in this level. Levallois debitage was found in older Mousterian sediments at Vindija (unit K) and at the nearby early Neandertal site of Krapina (Simek and Smith, 1997). There are specifically Upper Paleolithic elements (endscrapers and, possibly, a circumferentially engraved bear baculum) in the $\mathrm{G}_{3}$ assemblage. In terms of raw material use, the $\mathrm{G}_{3}$ assemblage comprises less quartz and more chert than do earlier Vindija Middle Paleolithic assemblages. This foreshadows the pattern of raw material use in the Vindija Upper Paleolithic, which is dominated by chert.

\section{Mosaic pattern of biocultural change}

The anatomy and behavior of the $\mathrm{G}_{3}$ hominids were more like the hominids that came after them in the region than they were like the Neandertals who came before them. Yet, the pattern of biocultural change is mosaic, and thus more complex, between levels $G_{3}$ and $G_{1}$. As previously noted by Karavanić (1995; Karavanić and Smith (1998) and others (e.g., Wolpoff et al., 1981; Smith and Ahern, 1994), the level $G_{1}$ tool assemblage, with its bone points and some Upper Paleolithic lithic elements, is dramatically different from that of level $G_{3}$, yet the hominids associated with these two levels are remarkably similar in the areas of anatomy that are preserved. The new archaeological interpretations and fossils reported here contribute to our understanding of this mosaic biocultural change. Unlike the $\mathrm{G}_{3}$ lithic assemblage, there are no tools made on quartz in the $G_{1}$ assemblage. The presence of Neandertals in level $G_{1}$ is affirmed by the new proximal radius shaft, Vi 13.8, which exhibits Neandertal-like shaft curvature and radial tuberosity orientation. Although some of the Neandertal-like features of the $G_{1}$ hominid fossils (e.g., retromolar space, maxillary incisor shoveling, horizontal-oval mandibular foramen) occur in low frequencies in early Upper Paleolithic modern humans, a medially oriented radial tuberosity, as exhibited by Vi 13.8, does not (Churchill, 1994). The complex of features possessed by the $G_{1}$ hominids can not be accommodated in modern human samples (Karavanic and Smith, 1998; Churchill and Smith, 2000). 
The mosaic pattern of Late Pleistocene biocultural change is incompatible with any simple explanation for the Neandertal-Middle Paleolithic/ modern-Upper Paleolithic transition in Europe. Although some lithic elements (such as endscrapers, blades, and bifacially retouched pieces) and the pattern of raw material use indicate cultural continuity between $\mathrm{G}_{3}$ and $\mathrm{G}_{1}$, the abrupt appearance of bone points does not (Karavanić and Smith, 1998). Furthermore, the presence of Neandertals in level $G_{1}$, dated to less than $30,000 \mathrm{ka}$, would seem to preclude gradual regional evolution of late Neandertals, as represented by the Vindija $\mathrm{G}_{3}$ hominids, into early modern Europeans. However, the timing of the appearance of the first modern humans in south-central Europe is still unknown. Although the Velika Pećina modern human frontal was once thought to be roughly contemporary with the $\mathrm{G}_{1}$ Neandertals (Karavanić and Smith, 1998), recent direct AMS radiocarbon dating places the Velika Pećina specimen within the Holocene (Smith et al., 1999). Nevertheless, modern humans were in central Europe, more than $200 \mathrm{~km}$ to the north at Mladec and Volgelherd (Stetten), during or before the time of the $G_{1}$ Neandertals (Churchill and Smith, 2000). Given this, it is possible that the $G_{1}$ artifact assemblage represents an acculturated industry, which resulted from complex interactions between modern humans and Neandertals (Karavanić and Smith, 1998). The persistence of Neandertal anatomy into Upper Paleolithic times at Vindija does not require that Neandertals and modern humans were separate species. The mosaic anatomy of the $G_{3}$ hominid sample and of a frontal specimen (Vi 308) from unit $\mathrm{G}_{1}$ (Wolpoff et al., 1981; Smith, 1984; Smith and Ahern, 1994), combined with the persistence of Neandertal traits in early Upper Paleolithic modern humans (Smith, 1984; Frayer, 1992; Frayer et al., 1993) and common Old World-wide biocultural evolutionary trends during the Pleistocene (Wolpoff, 1999), strongly suggest that Neandertals and modern humans were conspecific, except under the most narrow of species concepts. The Vindija $\mathrm{G}_{1}$ Neandertals may have been biological and, to a lesser degree perhaps, cultural "hold-outs" in a world that had otherwise changed.

\section{Summary and conclusions}

Since the Middle-Upper Paleolithic boundary roughly coincides with the disappearance of Neandertals and the appearance of early modern humans in Europe, the Vindija remains are important for understanding modern human biological and cultural origins. The newly associated partial cranium, Vi 284-230-255-256, is the most complete of the Vindija late Neandertals and demonstrates the mosaic nature of the Vindija $\mathrm{G}_{3}$ hominids. The seven new hominid fossils described here contribute new areas of anatomy to the Vindija sample as well as the first hominid fossils to be identified from stratigraphic Unit I. One of the new fossils, the Vi 13.8 radius, exhibits Neandertal-like shaft curvature and affirms the presence of Neandertals in the early Upper Paleolithic level $\mathrm{G}_{1}$. The newly identified probable bone retouchers from unit $G$ suggest that late Mousterian people at Vindija used both percussion and pressure techniques for retouching stone tools. Our reanalysis of the level $\mathrm{G}_{3}$ lithic assemblage demonstrates that the late Mousterian people at Vindija were using raw materials in a fashion somewhat different from early Mousterian people at the site and that this difference foreshadowed the raw material use pattern in the Vindija Upper Paleolithic. Finally, the pattern of biocultural change in south-central Europe, as documented by the Vindija collections, was mosaic. The cultural transition from the Middle to Upper Paleolithic did not coincide with the biological change from Neandertals to modern humans.

\section{Acknowledgements}

Dr. Maja Paunović, director of the Institute for Quaternary Geology and Paleontology and a coauthor of this paper, passed away February 23, 2003. Dr. Paunović's death was a great loss to Croatian science, to paleontology, and to her colleagues and family. All of the remaining authors (J.A., I.K., I.J., and F.S.) have been blessed by Dr. Paunović's generosity, hospitality, 
friendship, and intellect. We dedicate this paper to her memory.

We thank the Croatian Academy of Sciences and Arts for continued access to the Vindija fossils and for its continuing support of paleoanthropology in Croatia. Tomislav Šokec, Gordana Jambresić, Jakov Radovčić, Katica Kalac, Bob Franciscus, Preston Miracle, Sang-Hee Lee, Milford Wolpoff, George Gill, Rick Weathermon, Mary Lou Larson, Marcel Kornfeld, and anonymous reviewers provided various forms of assistance with respect to this report. We thank Tim D. White for originally identifying the fossils and probable retouchers, described here, as possibly being significant and worthy of further examination. Funding to J.A. from the Department of Anthropology, the Rackham School of Graduate Studies, and the International Institute of the University of Michigan and the Office of Research, University of Wyoming and to F.S. from the U.S. National Academy of Sciences and the Alexander von Humboldt Foundation supported portions of this project.

\section{References}

Ahern, J.C.M., 1998. Late Pleistocene frontals of the Hrvatsko Zagorje: an analysis of intrapopulational variation among south central European Neandertals. Ph.D. Dissertation, University of Michigan.

Ahern, J.C.M., 1999. Computational methods for addressing age and sex sample bias: a south-central European test case. Am. J. Phys. Anthrop. 27(Suppl.), 81-82.

Ahern, J.C.M., Smith, F.H., in press. Aspects of supraorbital torus morphology in the Le Moustier 1 adolescent Neandertal. In: Ullrich, H. (Ed.), The Neandertal Adolescent Le Moustier 1-New Aspects, New Results. Museum für Vor- und Frühgeschichte, Berlin.

Ahern, J.C.M., Lee, S-H., Hawks, J.D., 2002. The late Neandertal supraorbital fossils from Vindija Cave, Croatia: a biased sample? J. Hum. Evol. 43, 419-432.

Bartolomei, G., Broglio, A., Cassoli, P.F., Castalleti, L., Cattani, L., Cremachi, M., Giacobini, G., Malerba, G., Maspero, A., Peresani, M., Sartoreli, A., Tagliacozzo, A., 1994. La Grotte de Fumane. Un site aurignacien au pied des Alpes. Preistoria Alpina-Museo Tridentino di Science Naturali 28, 131-179.

Behrents, R., 1985. Growth in the Aging Craniofacial Skeleton. Center for Human Growth and Development, Ann Arbor, MI.
Binford, L.R., 1981. Bones: Ancient Men and Modern Myths. Academic Press, New York.

Blaser, F., Kurtanjek, D., Paunović, M., 2002. L'industrie du site néandertalien de la grotte de Vindija (Croatie): une révision des matières premières lithiques. L'Anthropologie 106, 387-398.

Blumenschine, R.J., Marean, C.W., Capaldo, S.D., 1996. Blind tests of inter-analyst correspondence and accuracy in the identification of cut marks, percussion marks, and carnivore tooth marks on bone surface. J. Archaeol. Sci. 23, 493-507.

Bonnichsen, R., Sorg, M.H. (Eds.), 1989. Bone Modification. Center for the Study of the First Americans, Orono.

Bordes, F., 1961. Typologie du Paléolithique ancien et moyen. Delmas, Bordeaux.

Bräuer, G., 1989. The evolution of modern humans: a comparison of the African and non-African evidence. In: Mellars, P., Stringer, C.B. (Eds.), The Human Revolution. Edinburgh University Press, Edinburgh, pp. 121-154.

Bräuer, G., 1992. Africa's place in the evolution of Homo sapiens. In: Bräuer, G., Smith, F.H. (Eds.), Continuity or Replacement: Controversies in Homo sapiens Evolution. Balkema, Rotterdam, pp. 83-98.

Carretero, J.M., Lorenzo, C., Arsuaga, J.L., 1999. Axial and appendicular skeleton of Homo antecessor. J. Hum. Evol. 37, 459-499.

Churchill, S.E., 1994. Human Upper Body Evolution in the Eurasian Later Pleistocene. Ph.D. Dissertation, University of New Mexico.

Churchill, S.E., Smith, F.H., 2000. Makers of the early Aurignacian of Europe. Yearb. Phys. Anthrop. 43, 61-115.

Flores, G.J., 2001. Greater sciatic notch variation between American Indians and Whites. Am. J. Phys. Anthrop. 32(Suppl.), 65.

Frayer, D.W., 1992. The persistence of Neandertal features in post-Neandertal Europeans. In: Bräuer, G., Smith, F.H. (Eds.), Continuity or Replacement: Controversies in Homo sapiens Evolution. A.A. Balkema, Rotterdam, pp. 179-188.

Frayer, D.W., Wolpoff, M.H., Smith, F.H., Thorne, A.G., Pope, G.G., 1993. The fossil evidence for modern human origins. Am. Anthrop. 95, 14-50.

Hirc, D., 1878. Vindija. In: Klaic, V. (Ed.), Prirodni žemljopis Hrvatske. Tiškom C. Albrechta, Zagreb, p. 699.

Hofbauer, A., Ahern, J.C.M., Lee, S-H., 2003. Craniofacial remodeling during adulthood: the supraorbital region. Am. J. Phys. Anthrop. 36(Suppl.), 115.

Howell, F., 1984. Introduction. In: Smith, F.H., Spencer, F. (Eds.), Origins of Modern Humans: A World Survey of the Fossil Evidence. Alan R. Liss, New York, pp. xiii-xxii.

Inizan, M.-L., Roche, H., Tixier, J., 1992. Technology of Knapped Stone. CREP, Meudon.

Israel, H., 1968. Continuing growth in the human cranial skeleton. Arch. Oral Biol. 13, 133-137.

Israel, H., 1971. The impact of aging upon the adult craniofacial skeleton. Ph.D. Dissertation, University of Alabama, Birmingham. 
Israel, H., 1973. Age factor and the pattern of change in craniofacial structures. Am. J. Phys. Anthrop. 39, 111-128.

Israel, H., 1977. The dichotomous patter of craniofacial expansion during aging. Am. J. Phys. Anthrop. 47, 47-52.

Karavanić, I., 1995. Upper Paleolithic occupation levels and late-occurring Neandertals at Vindija Cave (Croatia) in the context of central Europe and the Balkans. J. Anthrop. Res. $51,9-35$.

Karavanić, I., Smith, F., 1998. The Middle/Upper Paleolithic interface and the relationship of Neandertals and early modern humans in the Hrvatsko Zagorje, Croatia. J. Hum. Evol. 34, 223-248.

Karavanić, I., Smith, F., 2000. More on the Neanderthal problem. Curr. Anthrop. 41, 838-840.

Karavanić, I., Šokec, T., in press. The comparison of Middle Paleolithic percussion or pressure flaking tools. The comparison of experimental and archaeological material from Croatia. Prilozi Inst. Arheol. Zagreb.

Karavanić, I., Paunović, M., Yokoyama, Y., Falguéres, C., 1998. Néandertaliens et Paléolithique Supérieur dans la Grotte de Vindija, Croatie: controverses autour de la couche G1. L'Anthropologie 102, 131-141.

Klein, R., 1999. The Human Career: Human Biological and Cultural Origins, second ed. University of Chicago Press, Chicago.

Kozlowski, J., 1996. Cultural context of the last Neanderthals and early modern humans in central-eastern Europe. In: Bar-Yosef, O., Cavalli-Sforza, L., March, R., Piperno, M. (Eds.), The Lower and Middle Paleolithic. International Union of Prehistoric and Protohistoric Sciences, Forli, pp. 205-218.

Krings, M., Capelli, C., Tschentscher, F., Geisert, H., Meyer, S., von Haeseler, A., Grossschmidt, K., Possnert, G., Paunović, M., Pääbo, S., 2000. A view of Neandertal genetic diversity. Nature Genetics 26, 144-146.

Kurtanjek, D., Marci, V., 1990. Petrografska istraživanja paleolitskih artefakata spilje Vindije. Rad. Jugosl. Akad. Znan. Umjetn. 449, 227-238.

Leonardi, P., 1979. Una serie di ritoccatoi prevalentemente musteriani del Riparo Tagliente in Valpantena presso Verona. Prehistoria Alpina 15, 7-15.

Malez, M., 1975. Die Höhle Vindija: Eine neue Fundstelle fossiler Hominiden in Kroatien. Bulletin Scientifique du Conseil des Académies des Sciences et des Arts de la RSF Yougoslavie (Section A) 20, 139-141.

Malez, M., 1980. Sites of fossil men in Yugoslavia. Coll. Anthropol. 4, 13-29.

Malez, M., 1981. Paleolitik na području Zagreba, in: Rapanić, Ž. (Ed.), Arheološka istraživanja u Zagrebu i njegovoj okolici. Izdanja Hrvatskog arheološkog društva 6 . Hrvatsko arheološko društvo, Zagreb, pp. 65-108.

Malez, M., Rukavina, D., 1979. Položaj naslaga spilje Vindije u sustau članjenja Kvartara šireg područja Alpa. Rad. Jugosl. Akad. Znan. Umjetn. 383, 187-218.

Malez, M., Ullrich, H., 1982. Neuere palaanthropologische Untersuchungen am Matrial aus her Hohle Vindija (Kroatien, Jugoslawien). Palaeontol. Jugoslav. 29, 1-44.
Malez, M., Smith, F.H., Radovčić, J., Rukavina, D., 1980. Upper Pleistocene hominids from Vindija Cave, Croatia, Yugoslavia. Curr. Anthrop. 21, 365-367.

Malez, M., Šimunić, A., Šimunić, A., 1984. Geološki, sedimentološki i paleoklimatski odnosi špilje Vindije i bliže okolice. Rad. Jugosl. Akad. Znan. Umjetn. 411, 231-264.

Manly, B.F.J., 1997. Randomization, Bootstrap, and Monte Carlo Methods in Biology. Chapman and Hall, London.

Martin, H., 1906. Ossements utilisés par l'homme mousrérien de la station de la Quina (Charente). Bulletin de la Société Préhistorique Françe (séance du 26 avril), 1-8.

Martin, R., Saller, K., 1957. Lehrbuch der Anthropologie, second ed. Gustav Fischer, Stuttgart.

Miracle, P.T., 1998. The spread of modernity in Paleolithic Europe. In: Omoto, K., Tobias, P.V. (Eds.), Origins and Past of Modern Humans: Towards Reconciliation. World Scientific, Singapore, pp. 171-187.

Montet-White, A., 1996. Le Paléolithique en Ancienne Yougoslavie. Éditions Jérôme Millon, Grenoble.

Musil, R., Valoch, K., 1966. Beitrag zur Gliederung des Würms in Mitteleuropa. Eiszeitalt. Gegenw. 17, 131-138.

Nami, H.G., Scheinsohn, V.G., 1997. Use-wear patterns on bone experimental flakers: a preliminary report. In: Hannus, L.A., Rossum, L., Winham, R.P., (Eds.), Proceedings of the 1993 Bone Modification Conference. Augustana College, Sioux Falls, SD, pp. 256-264.

Obelić, B, Horvatinčić, N, Srdoč, D, Krajcar Bronić, I, Sliepčević, A., 1994. Rudjer Boskovic Institute radiocarbon measurements XIII. Radiocarbon 36, 303.

Paunović, M., Jambresic, G., Brajković, D., Malez, V., Lenardić, J.M., 2001. Last glacial settlement of Croatia: catalogue of fossil sites dated to the OIS 2 and 3. Acta Geologica 26, 27-70.

Patou-Mathis, M., 1997. Analyses taphonomique et palethnographique du matériel osseux de Krapina (Croatie): nouvelles données sur la faune et les restes humains. Préhistoire Européenne 10, 63-90.

Pearson, O.M., Grine, F.E., 1997. Reanalysis of the hominid radii from Cave of Hearths and Klasies River Mouth, South Africa. J. Hum. Evol. 32, 577-592.

Plisson, H., 1988. Technologie et tracéologie des outils lithiques moustériens en Union Soviétique: les travaux de V.E. Shchelinskiï. In: Otte, M. (Ed.), L'homme de Néandertal, Vol. 4: La Technique. ERAUL, Liege, pp. 121-168.

Rabeder, G., Großschmidt, K., Paunović, M., in prep. The Vindija Neandertals: Catalogue of Skeletal Remains.

Radovčić, J., Smith, F., Trinkaus, E., Wolpoff, M., 1988. The Krapina Hominids: An Illustrated Catalog of the Skeletal Collection. Mladost and the Croatian Natural History Museum, Zagreb.

Rak, Y., Kimbel, W.H., Hovers, E., 1994. A Neandertal infant from Amud Cave, Israel. J. Hum. Evol. 26, 313-324.

Rink, W., Schwarcz, H., Radovčić, J., Rukavina, D., Karavanić, I., Richter, D., 1999. ESR dating at the Croatian Paleolithic sites of Krapina, Vindija, and Mujina Pećina. Paper presented at: Krapina 1899-1999: The 
Krapina Neandertals and Human Evolution in central Europe (Zagreb, Croatia).

Russell, M., 1983. Browridge development as a function of bending stress in the supraorbital region. Am. J. Phys. Anthrop. 60(Suppl.), 248.

Simek, J.F., Smith, F.H., 1997. Chronological changes in stone tool assemblages from Krapina (Croatia). J. Hum. Evol. 32, 561-575.

Smith, F.H., 1976. The Neandertal remains from Krapina: a descriptive and comparative study. Univ. Tenn. Dept. Anthropol. Rep. Invest. 15, 1-359.

Smith, F.H., 1982. Upper Pleistocene hominid evolution in south-central Europe: a review of the evidence and analysis of trends. Curr. Anthrop. 23, 667-703.

Smith, F.H., 1984. Fossil hominids from the Upper Pleistocene of Central Europe and the origin of modern Europeans. In: Smith, F.H., Spencer, F. (Eds.), The Origins of Modern Humans: A World Survey of the Fossil Evidence. Alan Liss, New York, pp. 137-209.

Smith, F.H., 1994. Samples, species and speculations in the study of modern human origins. In: Niteki, M.H., Niteki, D.V. (Eds.), Origins of Anatomically Modern Humans. Plenum, New York, pp. 227-249.

Smith, F.H., Ahern, J.C., 1994. Additional cranial remains from Vindija Cave, Croatia. Am. J. Phys. Anthrop. 93, 275-280.

Smith, F.H., Ranyard, G., 1980. Evolution of the supraorbital region in Upper Pleistocene fossil hominids from southcentral Europe. Am. J. Phys. Anthrop. 53, 589-610.

Smith, F.H., Trinkaus, E., 1991. Les origins de l'homme moderne en Europe centrale: un case de continuité. In: Hublin, J.J., Tillier, A.M. (Eds.), Aux Origines D'Homo sapiens. Presses Universitaires de France, Paris, pp. 253-290.

Smith, F.H., Boyd, D.C., Malez, M., 1985. Additional Upper Pleistocene human remains from Vindija Cave, Croatia, Yugoslavia. Am. J. Phys. Anthrop. 68, 375-383.

Smith, F., Trinkaus, E., Pettitt, P., Karavanić, I., 1999. Direct radiocarbon dates for Vindija G1 and Velika Pećina Late Pleistocene hominid remains. Proc. natl. Acad. Sci. 96, 12281-12286

Srdoč, D, Obelić, B, Horvatinčić, N, Krajcar, I, Sliepčević, A., 1984. Rudjer Boskovic Institute radiocarbon measurements VIII. Radiocarbon 21, 449.

Straus, L.G., 1999. The Neanderthal problem continued. Curr. Anthrop. 40, 352-355.

Stringer, C.B., 1982. Comment on Upper Pleistocene evolution in south-central Europe: a review of the evidence and analysis of trends. Curr. Anthrop. 23, 690-691.

Stringer, C.B., Hublin, J.J., Vandermeersh, B., 1984. The origin of anatomically modern humans in western Europe. In: Smith, F.H., Spencer, F. (Eds.), The Origins of Modern Humans: a World Survey of the Fossil Evidence. Alan Liss, New York, pp. 51-135.
Stringer, C.B., Gamble, C., 1993. In Search of the Neandertals. Thames and Hudson, London.

Trinkaus, E., 1977. A functional interpretation of the axillary border of the Neandertal scapulae. J. Hum. Evol. 6, 231-234.

Trinkaus, E., 1983. Neandertal postcrania and the adaptive shift to modern humans. British Archaeological Reports International Series 164, 165-200.

Trinkaus, E., Churchill, S.E., 1988. Neandertal radial tuberosity orientation. Am. J. Phys. Anthrop. 75, 15-21.

Trinkaus, E., Smith, F.H., 1995. Body size of the Vindija Neandertals. J. Hum. Evol. 28, 201-208.

Turq, A., 1989. Approche technologique et économique du faciès Moustérien de type Quina: étude préliminaire. Bull. Soc. Préhist. Fr. 86, 244-256.

Valoch, K., 1968. Evolution of the Paleolithic in central and eastern Europe. Curr. Anthrop. 9, 351-390.

Valoch, K., 1978. Nové poznatky o paleolitu v Československu. Sborník Prací Filozofické Fakulty Brněnskě Univerzity 22/23, 7-25.

Valoch, K., 1981. Einige mittelpaläolithische Industrien aus der Kulna-Höhle im mährischen Karst. Časopois Morav. Mus. 64, 47-67.

Villa, P., Bartram, L., 1996. Flaked bone from a hyena den. Paleo 8, 143-159.

Vincent, A., 1988. L'os comme artefact au paléolithique moyen: principes d'étude et premiers résultats. In: Otte, M. (Ed.), L'homme de Néandertal, Vol. 4: La Technique. ERAUL, Liege, pp. 185-196.

Vuković, S., 1949. Prehistorijsko nalazište spilje Vindije. Historijski Zbornik 2, 243-249.

Vuković, S., 1950. Paleoliska kamena industrija spilije Vindija. Historiski Zbornik 3, 241-256.

Vuković, S., 1961. Mezolitska kamena industrija spilje Vindije. Godišnjak Gradskog Muzeja Varazdin 1, 9-32.

Vuković, S., 1970. Gravetijen spilje Vindije s osvrtom na gravetijen s podrucja sjeverne Italije, slovenskog Krasa i obale Istre. In: Mirosavljevic, V., Rendić-Mioćevic, D., Suić, M. (Eds.), Adriatica Praehistorica et Antiqua. Sveucilišta u Zagrebu, Zagreb, pp. 31-46.

Wild, E.M., Steffan, I., Rabeder, G., 1988. Uranium-series dating of fossil bones, progress report. Institut für Radiumforschung und Kernphysik Wien 53, 53-56.

Wild, E.M., Paunović, M., Rabeder, G., Steffan, I., Steier, P., 2001. Age determination of fossil bones from the Vindija Neanderthal site in Croatia. Radiocarbon 43, 1021-1028.

Wolpoff, M., 1999. Paleoanthropology, second ed. McGraw-Hill, New York.

Wolpoff, M., Smith, F.H., Malez, M., Radovčić, J., Rukavina, D., 1981. Upper Pleistocene hominid remains from Vindija Cave, Croatia, Yugoslavia. Am. J. Phys. Anthrop. 54, 499-545.

Zilhão, J., d'Errico, F., 1999. The Neanderthal problem continued: reply. Curr. Anthrop. 40, 355-364. 